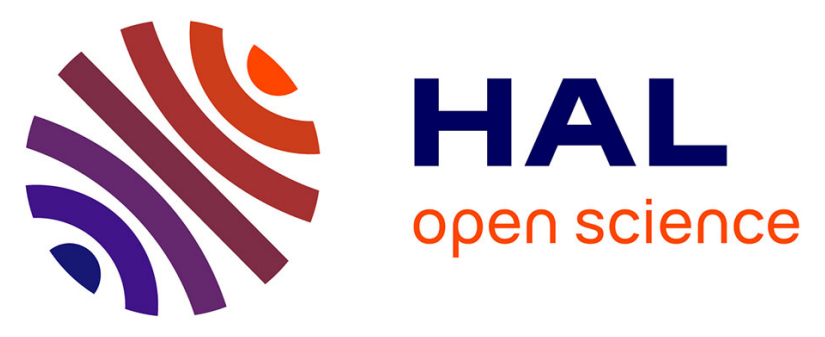

\title{
Effects of water vapour and temperature on the retention of radiotoxic CH3I by silver faujasite zeolites
}

Mouheb Chebbi, Bruno Azambre, Celine Monsanglant Louvet, Benoit Marcillaud, Audrey Roynette, Laurent Cantrel

\section{- To cite this version:}

Mouheb Chebbi, Bruno Azambre, Celine Monsanglant Louvet, Benoit Marcillaud, Audrey Roynette, et al.. Effects of water vapour and temperature on the retention of radiotoxic CH3I by silver faujasite zeolites. Journal of Hazardous Materials, 2020, 409, pp.124947. 10.1016/j.jhazmat.2020.124947 . hal-03151595

\section{HAL Id: hal-03151595 \\ https://hal.science/hal-03151595}

Submitted on 24 Feb 2021

HAL is a multi-disciplinary open access archive for the deposit and dissemination of scientific research documents, whether they are published or not. The documents may come from teaching and research institutions in France or abroad, or from public or private research centers.
L'archive ouverte pluridisciplinaire HAL, est destinée au dépôt et à la diffusion de documents scientifiques de niveau recherche, publiés ou non, émanant des établissements d'enseignement et de recherche français ou étrangers, des laboratoires publics ou privés.

\section{(ㅇ)(1) $\$$}

Distributed under a Creative Commons Attribution - NonCommercial - NoDerivatives| 4.0 


\section{Journal Pre-proof}

Effects of water vapour and temperature on the retention of radiotoxic $\mathrm{CH}_{3} \mathrm{I}$ by silver faujasite zeolites

M. Chebbi, B. Azambre, C. Monsanglant-Louvet, B. Marcillaud, A. Roynette, L. Cantrel

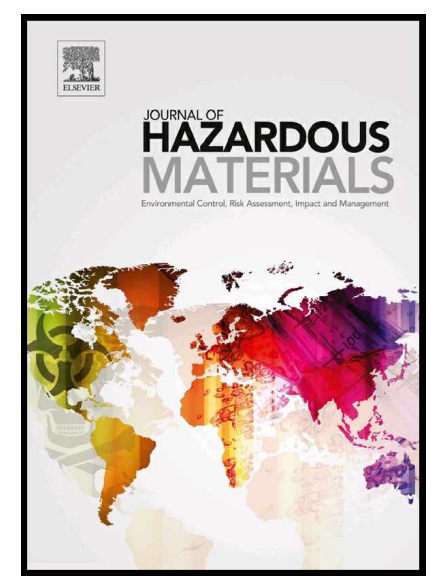

PII: $\quad$ S0304-3894(20)32938-1

DOI: $\quad$ https://doi.org/10.1016/j.jhazmat.2020.124947

Reference: HAZMAT124947

To appear in: Journal of Hazardous Materials

Received date: 11 September 2020

Revised date: 8 December 2020

Accepted date: 21 December 2020

Please cite this article as: M. Chebbi, B. Azambre, C. Monsanglant-Louvet, B. Marcillaud, A. Roynette and L. Cantrel, Effects of water vapour and temperature on the retention of radiotoxic $\mathrm{CH}_{3} \mathrm{I}$ by silver faujasite zeolites, Journal of Hazardous Materials, (2020) doi:https://doi.org/10.1016/j.jhazmat.2020.124947

This is a PDF file of an article that has undergone enhancements after acceptance, such as the addition of a cover page and metadata, and formatting for readability, but it is not yet the definitive version of record. This version will undergo additional copyediting, typesetting and review before it is published in its final form, but we are providing this version to give early visibility of the article. Please note that, during the production process, errors may be discovered which could affect the content, and all legal disclaimers that apply to the journal pertain.

(C) 2020 Published by Elsevier. 


\title{
Effects of water vapour and temperature on the retention of radiotoxic $\mathrm{CH}_{3}$ I by silver faujasite zeolites
}

\author{
M. Chebbi ${ }^{1^{*}}$, B. Azambre ${ }^{2}$, C. Monsanglant-Louvet ${ }^{1}$, B. Marcillaud ${ }^{1}$, A. Roynette ${ }^{1}$, L. \\ Cantrel $^{3}$
}

${ }^{1}$ Institut de Radioprotection et de Sûreté Nucléaire (IRSN), PSN-RES, SCA, Gif-sur-Yvette, 91192, France

${ }^{2}$ Université de Lorraine, Laboratoire de Chimie et Physique-Approche Multi-Echelle des Milieux Complexes (LCP-A2MC-EA n 4362), Institut Jean-Barriol FR2843 CNRS, ICPM, 1, Bd Arago, F-

57500 Saint-Avold, France

${ }^{3}$ Institut de Radioprotection et de Sûreté Nucléaire (IRSN), PSN-RES, SEREX, Saint-Paul Lez Durance, 13115, France

* Corresponding author:

mouheb.chebbi@irsn.fr

KEYWORDS: severe nuclear accident, $\gamma$-irradiation, adsorption, zeolites, iodine trap.

\begin{abstract}
In this work, $\mathrm{Ag} / \mathrm{X}$ and $\mathrm{Ag} / \mathrm{Y}$ faujasite zeolites were evaluated as candidate sorbents for the retention of methyl iodide under conditions close to those expected in a severe nuclear accident. Different categories of tests were conducted from laboratory to semi-pilot scales. First, the effects of temperature and water vapour on the $\mathrm{CH}_{3} \mathrm{I}$ retention/decomposition mechanism were investigated under lab-scale conditions. More specifically, the $\mathrm{CH}_{3} \mathrm{I}$ adsorption capacities and the fate of its main decomposition products (oxygenated compounds and alkanes) were measured under dynamic conditions at different temperatures $(35,100$ and $250{ }^{\circ} \mathrm{C}$ ). Then, the decontamination factors of $\mathrm{Ag} / \mathrm{X}$ and $\mathrm{Ag} / \mathrm{Y}$ silver faujasites exchanged
\end{abstract}


with different silver contents were monitored according to the time on stream using a very low $\mathrm{CH}_{3} \mathrm{I}$ concentration ( $1 \mathrm{ppmv}$ ). Finally, a parametric study was conducted at semi-pilot scale using realistic $\left[\mathrm{CH}_{3} \mathrm{I}\right] /\left[\mathrm{H}_{2} \mathrm{O}\right]$ molar ratio $\approx 10^{-6}$ and temperatures in the range $20-90^{\circ} \mathrm{C}$. Those experiments were helpful in order to assess the effects of some important parameters relevant to the adsorbents or operating conditions.

\section{Introduction}

Since the Fukushima Daiichi accident, many efforts have been performed in order to overcome the radiotoxic releases before they reach the environment. Among all potential fission products iodine is of specific interest because the ${ }^{131} \mathrm{I}$ isotope may significantly contribute to radiological consequences at short term [1,2].

A promising mitigation strategy for iodine capture consists in combining aerosol filtration devices such as wet scrubbers or solid filters with an additional filtration stage dedicated to the volatile forms of iodine. Typically, a robust porous adsorbent has to be specifically designed for the retention of gaseous $\mathrm{I}_{2}$ and alkyl iodides, namely $\mathrm{CH}_{3} \mathrm{I}$ [3]. Among the candidate adsorbent materials, zeolites were given in past and present works a central place thanks to their thermal stability, radiation resistance, high specific surface areas and tunable properties (pore size and connectivity, $\mathrm{Si} / \mathrm{Al}$ ratio, cation content) [4,5]. Hence, a large panel of candidate zeolites was tested in order to determine the most influent chemical and structural zeolitic parameters on the retention of volatile iodine species [6-12]. $\mathrm{CH}_{3} \mathrm{I}$ retention has been proved as more difficult than that of $\mathrm{I}_{2}$ on many types of sorbents. Silver zeolites, obtained from ion-exchange with silver nitrate (reduced or not with $\mathrm{H}_{2}$ ), were often claimed to be the best industrial adsorbents for $\mathrm{CH}_{3} \mathrm{I}$ capture. Indeed, the tendency of silver sorbents to form thermally stable and insoluble $\mathrm{AgI}$ precipitates from $\mathrm{CH}_{3} \mathrm{I}$ adsorption has been known for long. Nevertheless, it was clearly established in our previous lab-scale studies $[6,9,10,12]$ that $\mathrm{CH}_{3} \mathrm{I}$ adsorption by silver zeolites is affected both by the amount, the dispersion, the 
oxidation state and accessibility of silver sites in the framework. In that respect, exchanged faujasite (FAU) zeolites with high silver contents exhibited the highest retention performances in comparison with other kinds of silver zeolites. Indeed, as the silver content reached $20 \mathrm{wt} \%$ or more in exchanged $\mathrm{X}$ or $\mathrm{Y}$ zeolites, very high adsorption capacities and irreversible trapping could be obtained. This was explained by the superior cationic exchange capacity of faujasite zeolites (in line with their lower $\mathrm{Si} / \mathrm{Al}$ ratio [13]), promoting the dispersion of large amounts of silver in $+\mathrm{I}$ oxidation state. By contrast with metallic nanoparticles, cationic silver is the preferred silver state for $\mathrm{CH}_{3} \mathrm{I}$ trapping [12]. Moreover, the large pore size and 3D character of faujasites make them less prone than other zeolitic frameworks (e.g. mordenite) to porosity blockage by $\mathrm{AgI}$ entities in the course of $\mathrm{CH}_{3} \mathrm{I}$ adsorption [9].

Despite all the made progresses about the comprehension of both the mechanistic aspects and the most prominent factors governing the retention of the targeted species during our lab scale studies [6-12], numerous uncertainties remain about the behavior of silver faujasite adsorbents under severe nuclear accident conditions. In that respect, water vapour is thought to be the main inhibiting compound because present in very large excess compared with $\mathrm{CH}_{3} \mathrm{I}$ (molar ratio expected to be $\approx 10^{-6}[4]$ ). Nevertheless, its effect on $\mathrm{CH}_{3} \mathrm{I}$ retention was reported either to be beneficial or detrimental depending on the nature of the tested zeolites and the investigated conditions $[5,6]$. On the one hand, it has been reported $[14,15]$ that moderate amounts of water vapour in the feed gas $\left(\mathrm{CH}_{3} \mathrm{I}\right] /\left[\mathrm{H}_{2} \mathrm{O}\right] \sim 4.10^{-3}$, temperature $100-150{ }^{\circ} \mathrm{C}, \mathrm{R} . \mathrm{H}$. $=5.6 \%$ at $100{ }^{\circ} \mathrm{C}$ and $1.2 \%$ at $150{ }^{\circ} \mathrm{C}$ ) slightly enhance the $\mathrm{CH}_{3} \mathrm{I}$ adsorption capacity of $\mathrm{Ag}^{\circ}$ MOR zeolites (containing 9-15 wt $\%$ of silver and $\mathrm{Si} / \mathrm{Al}=10$ ). However, lower retention performances were observed at higher relative humidity. On the other hand, the presence of $\mathrm{H}_{2} \mathrm{O}$ either in the gas mixture (R.H. $=50 \%$, temperature $150-250{ }^{\circ} \mathrm{C}[16]$ ) or in the pores of the material $(18 \mathrm{wt} \%,[17])$ was found in other studies to negatively impact the $\mathrm{CH}_{3} \mathrm{I}$ retention performances of $\mathrm{Ag}-\mathrm{X}$ zeolites with $\mathrm{Si} / \mathrm{Al}$ ratio of 1.2 and $10-16 \mathrm{wt} \%$ of silver. Furthermore, 
it was stated that detrimental effect related to the initial hydration state of the zeolite seems to occur especially at low temperatures $\left(20-30{ }^{\circ} \mathrm{C}[17]\right)$. To sum-up, the effect of water on $\mathrm{CH}_{3} \mathrm{I}$ adsorption may rely on different parameters, namely the zeolite $\mathrm{Si} / \mathrm{Al}$ ratio, which affects its hydrophilic/hydrophobic character, but also the adsorption temperature and the $\left[\mathrm{CH}_{3} \mathrm{I}\right] /\left[\mathrm{H}_{2} \mathrm{O}\right]$ molar ratio. Hence, mildly hydrophobic zeolites (e.g. with $\mathrm{Si} / \mathrm{Al}$ ratio higher than 10-15) should display a better tolerance to water than more hydrophilic zeolites but in turn, the $\mathrm{CH}_{3} \mathrm{I}$ retention efficiency could also be decreased by the smaller amounts of exchanged silver sites in the former materials. On the other hand, the behaviour of a zeolitic adsorbent could also be influenced by textural parameters, such as the type of framework [10] and the size of zeolite crystallites [9]. Those latter parameters are expected to influence the intracrystalline diffusion of iodine species and the accessibility to silver sites not yet transformed as AgI precipitates. Hence, a compromise has to be found between all these aspects in order to find an optimal zeolitic sorbent to trap volatile iodine even in the presence of large excess of water vapour.

This study represents to the best of our knowledge a definitive advance on how silver faujasite zeolites may behave for iodine capture in severe conditions. More particularly, the effects of temperature and $\left[\mathrm{CH}_{3} \mathrm{I}\right] /\left[\mathrm{H}_{2} \mathrm{O}\right]$ ratio on the $\mathrm{CH}_{3} \mathrm{I}$ sorption properties of silver-exchanged faujasite (X and $\mathrm{Y}$ ) zeolites are investigated through the use of three complementary experimental setups. First, the effects of temperature and presence of water vapour on $\mathrm{CH}_{3} \mathrm{I}$ retention are studied at lab-scale conditions with the aims of determining the adsorption capacities and to ascertain some mechanistic aspects of the adsorption process. Then, the temporal evolution of $\mathrm{CH}_{3} \mathrm{I}$ Decontamination Factors (DF) are compared for some silver faujasite $\mathrm{X}$ and $\mathrm{Y}$ adsorbents at a $\mathrm{CH}_{3} \mathrm{I}$ concentration representative of a nuclear accident (1 ppmv). Finally, specific experiments at a semi-pilot scale were conducted for the first time under challenging and realistic conditions in order to unravel the relative influences of many 
experimental factors pertaining to processing conditions or to the adsorbing medium on the measured decontamination factors.

\section{Experimental section}

\subsection{Presentation of investigated adsorbents}

\subsubsection{Parent zeolites}

A commercial faujasite $\mathrm{Y}$ zeolite $(\mathrm{Si} / \mathrm{Al}=2.5, C B V 300)$ was provided by Zeolyst under ammonium form and is denoted $\mathrm{NH}_{4} / \mathrm{Y}(1.2)$ thereafter. The $13 \mathrm{X}(\mathrm{NaX})$ zeolite $(\mathrm{Si} / \mathrm{Al}=1.2$, 60-80 mesh, $20305, \% \mathrm{Na} \approx 10 \mathrm{wt} \%$ ) was supplied by Sigma Aldrich.

\subsubsection{Preparation of silver-exchanged zeolites}

Silver zeolites were prepared by ion-exchange of the parent zeolites with different silver nitrate solutions $\left(\mathrm{AgNO}_{3}\right.$ salt supplied by Sigma Aldrich, purity $\left.>99.9 \%\right)$. In order to increase the silver content, this ion-exchange procedure was repeated up to three times. Exchange reactions were achieved at $25^{\circ} \mathrm{C}$ and a $\mathrm{pH}$ of 5 for 24 hours. Experimental conditions as well as measured silver contents are detailed in supplementary information (see Table S1 in ESI) for all prepared silver zeolitic materials. After each ionic exchange reaction, samples were vacuum-filtered, washed with distilled water and dried at $80^{\circ} \mathrm{C}$ overnight. Prior to adsorption and characterization studies, zeolitic materials were thermally treated under air in a muffle furnace with a heating rate of $5^{\circ} \mathrm{C} \cdot \mathrm{min}^{-1}$ from room temperature to $200^{\circ} \mathrm{C}$ (plateau of $1 \mathrm{~h}$ ), and then to $500^{\circ} \mathrm{C}$ (heating rate of $5^{\circ} \mathrm{C} \cdot \mathrm{min}^{-1}$ and plateau of $2 \mathrm{~h}$ ). All preparation steps and samples storage were done in the dark in order to avoid any photoreduction of silver species. The obtained zeolitic samples were denoted during our study as $x \mathrm{Ag} / \mathrm{structure}(\mathrm{Si} / \mathrm{Al})$, where $\mathrm{x}$ is the silver content.

A "benchmark" $\mathrm{Ag} / 13 \mathrm{X}$ zeolite $\left(\mathrm{Si} / \mathrm{Al}=1.2,382280, \mathrm{Ag}_{84} \mathrm{Na}_{2}\left[\left(\mathrm{AlO}_{2}\right)_{86}\left(\mathrm{SiO}_{2}\right)_{106}\right] \cdot \mathrm{xH}_{2} \mathrm{O}\right)$ with $35 \mathrm{wt} \%$ of silver was also purchased from Sigma-Aldrich for comparison purposes. In the following, this adsorbent is denoted as $35 \mathrm{Ag} / 13 \mathrm{X}_{\text {comm }}$ (1.2). 


\subsection{Physico-chemical characterization studies}

The different studied sorbents were fully characterized to gain insights on their chemical, textural and structural properties. Elemental ICP analyses (Ag, Na, Al and Si), powder X-ray Diffraction (PXRD) measurements, $\mathrm{N}_{2}$ adsorption-desorption isotherms at $77 \mathrm{~K}$ as well as DRS-UV-Visible spectroscopic analyses were then performed. Detailed experimental procedures and associated results have been already presented during our previous works [712]. A summary of characterization data is presented in Electronic Supporting Information (Table S2).

In the present study, the morphology of some zeolites was also assessed from Scanning Electronic microscopic (SEM) characterizations. These analyses were performed on a JEOL (JSM 6010-LV) microscope. Powdered samples were deposited on an aluminum grid coated with a thin layer of adhesive carbon. The micrographs (Figure S1) were then recorded at $40 \mathrm{~Pa}$ and $15 \mathrm{kV}$, without any pre-metallization treatment.

\section{3. $\mathrm{CH}_{3} \mathrm{I}$ gas-phase dynamic sorption experiments}

Three different dynamic experimental setups were used in order to examine the $\mathrm{CH}_{3} \mathrm{I}$ retention behavior of silver faujasite sorbents under a wide range of conditions. Those conditions cover initial concentrations of methyl iodide from 1300 down to $0.15 \mathrm{ppmv}$, temperatures from 20 to $100{ }^{\circ} \mathrm{C}$ and $\left[\mathrm{CH}_{3} \mathrm{I}\right] /\left[\mathrm{H}_{2} \mathrm{O}\right]$ molar ratio from 0.13 to $10^{-6}$. A general overview of the used operated conditions within these three test benches is reported in Table 1. A detailed description of each experimental setup is presented in the following sections.

Table 1 : Comparison between the employed conditions for the three investigated dynamic experimental setups.

\begin{tabular}{|c|c|c|c|c|c|c|}
\hline Setup & Scale & $\begin{array}{c}{\left[\mathrm{CH}_{3} \mathrm{I}\right](\mathbf{p p m v})} \\
\{\text { carrier gas\} }\end{array}$ & {$\left[\mathrm{CH}_{3} \mathbf{I}\right] /\left[\mathrm{H}_{2} \mathrm{O}\right]$} & R.H. $(\%) / \mathrm{T}\left({ }^{\circ} \mathrm{C}\right)$ & $\begin{array}{c}\text { Bed } \\
\text { depth } \\
(\mathrm{cm})\end{array}$ & $\begin{array}{c}\text { Face } \\
\text { Velocity }^{*} \\
\left(\mathrm{~cm}^{*} \mathrm{~s}^{-1}\right)\end{array}$ \\
\hline Test bench 1 & Laboratory & 1333 \{Argon\} & 0.13 & $1 / 100$ & 1 & 11 \\
\hline
\end{tabular}




\begin{tabular}{|c|c|c|c|c|c|c|}
\hline Test bench 2 & Laboratory & $1\{$ Air $\}$ & No water & $0 / 25$ & 1 & 21 \\
\hline Test bench 3 & Semi-pilot & $0.15\{$ Air $\}$ & $6 \times 10^{-6}$ & $90 / 20$ or $10 / 80$ & $3-5$ & 10 \\
\hline
\end{tabular}

"The gas velocity was expressed at the studied temperature for each setup.

\subsubsection{Parametric tests at high concentrations of methyl iodide: effects of temperature and} water vapour (test bench 1)

First, the effects of temperature and water vapour on the $\mathrm{CH}_{3} \mathrm{I}$ retention properties of 22.8Ag/Y (2.5) zeolite were investigated at the laboratory scale using an experimental setup similar to the one used previously for the screening of silver zeolites [9] or Metal-Organic Frameworks (MOFs) [18]. In the present study, it was adapted to allow the co-generation of water vapour and methyl iodide at well-defined concentrations. Thanks to the high used $\mathrm{CH}_{3} \mathrm{I}$ concentration (1333 ppmv, balance argon), adsorption capacities at breakthrough and at saturation of the silver zeolite bed could be accurately measured in a period of a few hours. Moreover, the concentrations of water and some of the most important gaseous catalytic byproducts (methanol, dimethylether...) were monitored in real-time using a home-made on-line FTIR detection/quantification methodology (see Table S3 in ESI).

Briefly, about $200 \mathrm{mg}$ of the $22.8 \mathrm{Ag} / \mathrm{Y}$ (2.5) sorbent (grain size between 200 and $630 \mu \mathrm{m}$, bed depth $=1 \mathrm{~cm}$ ) were placed inside a quartz tube (internal diameter of $6 \mathrm{~mm}$ ), itself loaded in a tubular fixed bed reactor (Carbolite MTF furnace with Eurotherm temperature controller). An in situ pretreatment up to $500{ }^{\circ} \mathrm{C}$ was carried out in order to remove any adsorbed impurity from the zeolite before test. For $\mathrm{CH}_{3} \mathrm{I}$ adsorption tests performed under dry conditions, the temperature of the reactor was set either to $35.0,100.0$ or $250.0^{\circ} \mathrm{C}\left( \pm 0.1{ }^{\circ} \mathrm{C}\right)$. In order to gain insights on the influence of water vapour on the adsorption behavior, several experiments were conducted: (i) adsorption of $\mathrm{CH}_{3} \mathrm{I}$ in a completely dry atmosphere $\left(\left[\mathrm{CH}_{3} \mathrm{I}\right]=1333\right.$ ppmv/Ar, $\left.\mathrm{T}=100{ }^{\circ} \mathrm{C}\right)$; (ii) co-adsorption of $\mathrm{CH}_{3} \mathrm{I}$ and $\mathrm{H}_{2} \mathrm{O}\left(\left[\mathrm{H}_{2} \mathrm{O}\right]=10000 \mathrm{ppmv} / \mathrm{Ar}\right.$, 
$\left.\left[\mathrm{CH}_{3} \mathrm{I}\right] /\left[\mathrm{H}_{2} \mathrm{O}\right]=0.13, \mathrm{~T}=100{ }^{\circ} \mathrm{C}\right)$; (iii) saturation of the zeolite bed by water vapour $\left(\left[\mathrm{H}_{2} \mathrm{O}\right]\right.$ $=30000 \mathrm{ppmv} / \mathrm{Ar}, \mathrm{T}=100^{\circ} \mathrm{C}$ ) then adsorption of $\mathrm{CH}_{3} \mathrm{I}$ as in (i).

Methyl iodide and water vapour were generated from a certified $\mathrm{CH}_{3} \mathrm{I} / \mathrm{Ar}$ bottle (Air Products, $\left[\mathrm{CH}_{3} \mathrm{I}\right]=2000 \mathrm{ppmv} \pm 0.5 \%$, argon) and a thermostated bath containing a water saturator, respectively. The amount of $\mathrm{H}_{2} \mathrm{O}$ generated could be deduced from the saturator temperature, according to the Antoine equation [19]:

$$
\log \left(P_{H 2 O}\right)=A-\frac{B}{C+T}
$$

Where $P_{H 2 O}$ is the partial pressure of water vapor, $T(K)$ is the saturator temperature, and $A, B$, $C$ are specific constants for a given temperature range $\{\mathrm{A}=6.210, \mathrm{~B}=2,354.731$ and $\mathrm{C}=$ 7.559 for $\mathrm{T}=293-343 \mathrm{~K}\}$ [19].

The concentrations of the two gases at the reactor inlet were set using mass-flow controllers (Brooks 5850s) and argon as diluting gas (total flow rate $150 \mathrm{~mL} \cdot \mathrm{min}^{-1}$ ). All transfer lines were heated to $100{ }^{\circ} \mathrm{C}$ in order to avoid any loss by condensation. The composition of the reactor outflow was monitored continuously (every 2 minutes) using a heated FTIR gas cell (Cyclone series - Specac, $\mathrm{T}=120{ }^{\circ} \mathrm{C}$, optical path length of $2 \mathrm{~m}, \mathrm{~V}=0.19 \mathrm{~L}$ ) coupled to a Varian Excalibur 4100 FTIR spectrometer equipped with a DTGS detector. From the employed conditions (initial concentration of $\mathrm{CH}_{3} \mathrm{I}$ and detection limit of the FTIR gas cell), it was found [9] that decontamination factors $\left(D F=\frac{\left[\mathrm{CH}_{3} \mathrm{I}\right]_{\text {in }}}{\left[\mathrm{CH}_{3} \mathrm{I}\right]_{\text {out }}}\right)$ values of the order of $10^{2}$ can be guaranteed during the total retention step (before filter breakthrough).

\subsubsection{Retention performances at room temperature and low concentrations of methyl iodide:} test bench 2 (BRIOCH)

Accurate DF were measured under iodine concentrations more representative to those of a severe nuclear accident (0.1-1 ppmv [4]) thanks to the test bench 2 [20] (Figure S2). Retention tests were performed at room temperature, dry conditions and with inlet $\mathrm{CH}_{3} \mathrm{I}$ 
concentration of 1 ppmv/ $\mathrm{N}_{2}$ (certified calibrated gas from Air Products). Prior to adsorption tests, an ex-situ pretreatment was performed on the zeolitic sorbent at $200{ }^{\circ} \mathrm{C}$ during about 3 hours, in order to remove most of adsorbed moisture. Then, the gaseous flow $\left(\mathrm{CH}_{3} \mathrm{I} / \mathrm{N}_{2}, \mathrm{C}_{0}=\right.$ $1 \mathrm{ppmv}$, total flow rate $=150 \mathrm{nmL} \cdot \mathrm{min}^{-1}$ ) was fed at room temperature to a home-made fixed bed reactor containing the sorbent (mass of $100 \mathrm{mg}$, bed length $\approx 1 \mathrm{~cm}$, grain size between 200-630 $\mu \mathrm{m}$ ), placed itself in a glass tube (internal diameter of $4 \mathrm{~mm}$ ) and maintained between two pieces of quartz wool. The last part of the system is the GC detection/quantification instrument. It consists in a PerkinElmer 580 gas chromatograph, equipped with a high-sensitivity PDECD (pulsed discharge electron capture detector [21], Valco instruments) specific for halogenated compounds. $\mathrm{CH}_{3} \mathrm{I}$ concentrations between $10 \mathrm{pptv}$ and 2 ppmv could be measured and the GC was calibrated using certified gas bottles and mass-flow controllers. On-line measurements were carried out using the TotalChrom Navigator software by acquisition of chromatograms (referenced to air background) every 6 minutes during $\mathrm{CH}_{3} \mathrm{I}$ retention tests. Considering the detection limit (10 pptv), a maximum theoretical decontamination factor of $10^{5}$ can be reached for an inlet concentration of $\approx$ 1 ppmv.

\subsubsection{Retention properties from semi pilot-scale experiments: test bench 3 (PERSEE)}

The PERSEE Facility $[20,22]$ was used in order to extrapolate the behavior of some selected zeolitic sorbents towards the capture of methyl iodide at semi-pilot scale, using conditions closer to severe nuclear accident (relative humidity, $\gamma$-radiation, temperature). A general scheme of this facility is given in Figure S3 (see ESI). More particularly, a specific setup ("low flow rates", Figure 1) was used during our present work to explore retention performances of some silver-exchanged zeolites towards $\gamma$-labelled methyl iodide. This experimental setup (Figure 1) can be divided schematically into three main parts: (i) the generation of labelled $\mathrm{CH}_{3} \mathrm{I}$ and water vapour, (ii) the adsorbent holders (upstream stage) and 
(iii) the commercial cartridges of activated carbon (downstream stage) devoted to trap the fraction of methyl iodide not retained by the tested adsorbent.

Zeolitic samples were first homogenously mixed within a matrix of commercial sand. The purpose of this dilution was to achieve reasonable bed depths (ranging from 3 to $5 \mathrm{~cm}$ ). Attention was paid to ensure a good dispersion of the zeolitic material within the sand in the sample holder. Preliminary studies have shown that the used sand is totally ineffective for the retention of labelled methyl iodide ( $\mathrm{DF}=1[20,22])$. The different materials to be tested were placed in the upstream stage, giving the possibility to test simultaneously four different solid mixtures \{tested zeolite + sand (Figure 1). Prior to retention tests, the sample holders (internal diameter of $40 \mathrm{~mm}$ ) were heated at $80{ }^{\circ} \mathrm{C}$ under flowing air (flow rate $8 \mathrm{NL} . \mathrm{min}^{-1}$ ). Then, a fixed and reproducible concentration of water vapour (about 25000 ppmv) was generated using a heat plate evaporating water droplets by droplets. This concentration corresponds to a high relative humidity (R.H.) of $90-95 \%$ at a temperature of $20{ }^{\circ} \mathrm{C}$ and a rather low R.H. about $5-8 \%$ at $80^{\circ} \mathrm{C}$.

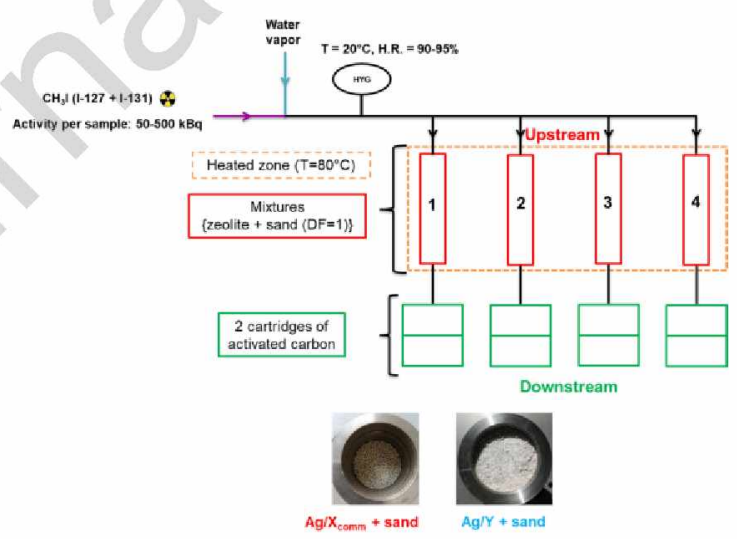

Figure 1 : Schematic representation of the « low flow rates » bench test of PERSEE.

Different sensors were placed in order to monitor the different test parameters, especially the temperature and the relative humidity of flowing gas before and within the heated zone (Figure 1). Sample characteristics as well as test parameters will be reported later in section 3.3. 
Once the equilibrium of water vapour generation was reached, a pulse (duration of $30 \mathrm{~min}$ ) of $\gamma$-labelled $\mathrm{CH}_{3} \mathrm{I}\left(\mathrm{C}_{0}=0.15 \mathrm{ppmv}\right)$ was generated from the following reaction:

$\left(\mathrm{CH}_{3} \mathrm{O}\right)_{2} \mathrm{SO}_{2}+2 \mathrm{NaI} \rightleftharpoons \mathrm{Na}_{2} \mathrm{SO}_{4}+2 \mathrm{CH}_{3} \mathrm{I}$

Depending on the studied sample, the iodine initial activity was in the range of $50-500 \mathrm{kBq}$ (Table 1). In each experiment, the labelled methyl iodide is transported by the air flow through zeolite holders with a velocity about $10 \mathrm{~cm} \cdot \mathrm{s}^{-1}$ at $80{ }^{\circ} \mathrm{C}$ (flow rate of $8 \mathrm{NL} \cdot \mathrm{min}^{-1}$ ). The total duration of retention tests was fixed to $30 \mathrm{~min}$. Then, samples were kept in equilibrium with the flowing air (R.H. of $5-8 \%$ at $80{ }^{\circ} \mathrm{C}$ ) for a period of one hour. Finally, ex-situ $\gamma$ spectrometry measurements were carried out both on the upstream and downstream stages. Decontamination factors (DF) were then deduced according to (2):

$D F=\frac{A_{\text {upstream }}+A_{\text {downstream }}}{A_{\text {downstream }}}$

where $A_{\text {upstream }}$ and $A_{\text {downstream }}$ are the measured activities respectively on the upstream and the downstream stages (Figure 1).

\section{Results and Discussion}

\subsection{Effects of temperature and humidity on the $\mathrm{CH}_{3} \mathrm{I}$ adsorption behavior of $22.8 \mathrm{Ag} / \mathrm{Y}$}

\section{(high concentration studies)}

In our previous studies $[6,9,10,12]$, it was shown that an ion-exchanged $\mathrm{Ag} / \mathrm{Y}$ zeolite containing $\approx 23 \mathrm{wt} \%$ of silver $(22.8 \mathrm{Ag} / \mathrm{Y}(2.5))$ displayed superior adsorption properties among a dozen of zeolitic formulations, both in terms of useful working adsorption capacities and trapping stability. Hence, this peculiar zeolite was selected here as a suitable candidate for further studies, in conditions closer to those met in nuclear accident. First, the effect of the adsorption temperature is addressed. Secondly, the effect of humidity, under several configurations, is assessed. 


\subsubsection{Effect of adsorption temperature}

The $22.8 \mathrm{Ag} / \mathrm{Y}(2.5)$ zeolite (pretreated in situ at $500{ }^{\circ} \mathrm{C}$ ) was exposed in a flow-through configuration to $\mathrm{CH}_{3} \mathrm{I}(1333 \mathrm{ppmv} / \mathrm{Ar})$ at $\mathrm{T}=35,100$ and $250{ }^{\circ} \mathrm{C}$. Experiments were carried out up to saturation of the bed in order to determine the adsorption capacities at saturation or

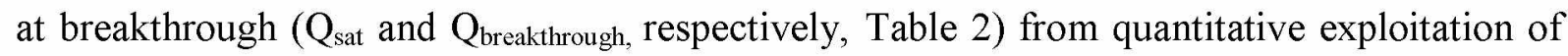
corresponding $\mathrm{CH}_{3} \mathrm{I}$ breakthrough curves displayed on Figure 2 (A). The $\mathrm{L}_{\mathrm{T}} / \mathrm{L}$ parameter representative of the diffusional constraints at the zeolite bed is also provided in Table 2, likewise the fraction of $\mathrm{CH}_{3} \mathrm{I}$ which could be removed by simple evacuation under inert atmosphere at the same temperature (denoted as \% weakly adsorbed $\mathrm{CH}_{3} \mathrm{I}$ in Table 2).

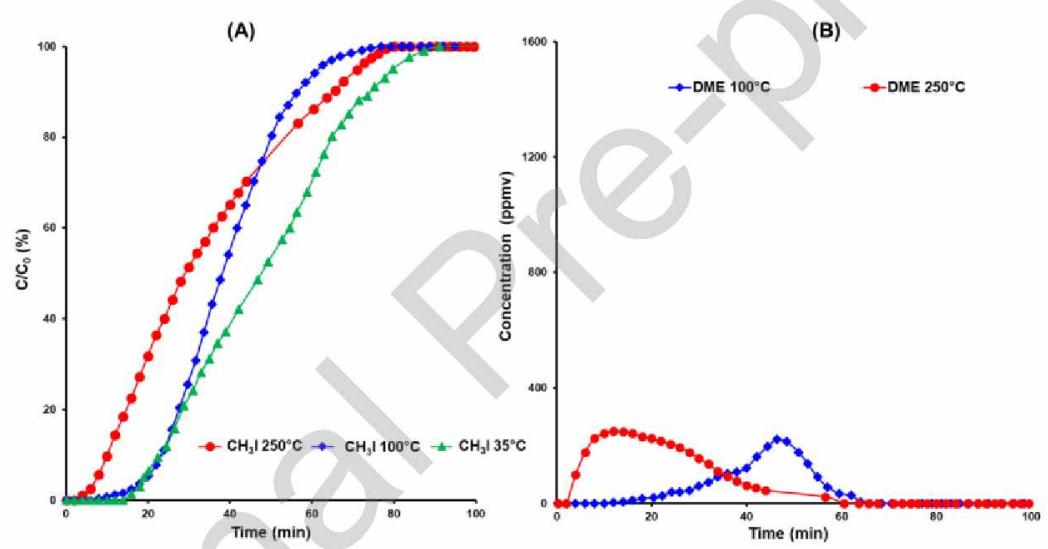

Figure 2 : (A) $\mathrm{CH}_{3} \mathrm{I}$ breakthrough curves and (B) temporal evolution of organic by-products during the adsorption of $\mathrm{CH}_{3} \mathrm{I}$ at various temperatures. $\left(22.8 \mathrm{Ag} / \mathrm{Y}(2.5), \mathrm{C}_{0}=1333 \mathrm{ppmv}\right)$. Similar scales were used on Figure 2 (B) and Figure 3 for comparison purposes.

As deduced from the data gathered in Table 2, a moderate decrease (about 23\%) of the adsorption capacity at saturation ( $Q_{\text {sat, }}$ Table 2$)$ was observed when the adsorption temperature increases from 35 to $250{ }^{\circ} \mathrm{C}$. This evolution can be paralleled to the amount of weakly adsorbed $\mathrm{CH}_{3} \mathrm{I}$ at the different adsorption temperatures $\left(21 \%\right.$ at $35{ }^{\circ} \mathrm{C}$, compared to 7 $\%$ at 100 and $250{ }^{\circ} \mathrm{C}$, Table 2). Hence, the trends observed about adsorption capacities at saturation $\left(\mathrm{Q}_{\text {sat }}\right)$ can be assigned to the existence of physisorption phenomena, which are promoted preferentially at low temperatures $[6,23,24]$. Overall, this result is in agreement with the previous works of Choi et al. [25]. Indeed, a decrease of $\mathrm{CH}_{3} \mathrm{I}$ adsorption capacity 
from 180 to $130 \mathrm{mg} / \mathrm{g}$ was reported when the temperature was increased from 100 to $400{ }^{\circ} \mathrm{C}$ (Ag-X zeolite with $10 \mathrm{wt} \%$ silver). Similar results were also found during the works of Belapurkar et $a l$. [17] related to $\mathrm{CH}_{3} \mathrm{I}$ adsorption by dehydrated $\mathrm{Ag}-\mathrm{X}$ zeolites (silver content of $16 \mathrm{wt} \%$ ) at temperatures ranging from 25 to $150{ }^{\circ} \mathrm{C}$.

Table 2 : Effect of temperature on the $\mathrm{CH}_{3} \mathrm{I}$ retention properties of $22.8 \mathrm{Ag} / \mathrm{Y}(2.5)$ zeolite $\left(\mathrm{C}_{0}=1333 \mathrm{ppmv} / \mathrm{Ar}\right)$.

\begin{tabular}{|cccccc|}
\hline Temperature $\left({ }^{\circ} \mathbf{C}\right)$ & $\mathbf{Q}_{\text {sat }}(\mathbf{m g} / \mathbf{g})$ & $\mathbf{Q}_{\text {breakthrough }}(\mathbf{m g} / \mathbf{g})$ & $\mathbf{t}_{\mathbf{5} \%}(\mathbf{m i n})$ & $\mathbf{L}_{\mathbf{T}} / \mathbf{L}^{*}$ & $\begin{array}{c}\text { \% of weakly }^{* * *} \\
\text { adsorbed CH}_{3} \mathbf{I}\end{array}$ \\
\hline 35 & $250 \pm 15$ & $100 \pm 11$ & $19 \pm 5$ & $0.79 \pm 0.02$ & $21 \pm 4$ \\
\hline 100 & $223 \pm 13$ & $90 \pm 10$ & $20 \pm 5$ & $0.70 \pm 0.02$ & $7 \pm 2$ \\
\hline 250 & $193 \pm 12$ & $43 \pm 5$ & $8 \pm 2$ & $0.90 \pm 0.03$ & $7 \pm 2$ \\
\hline
\end{tabular}

$* \frac{L_{T}}{L}=\frac{t_{f}-t_{5 \%}}{t_{f}}$

${ }^{* *}$ denotes the fraction which can be removed by changing the gas composition to pure argon.

Comparing now the length of the period of total retention (i.e. before breakthrough), the $22.8 \mathrm{Ag} / \mathrm{Y}(2.5)$ zeolite displayed very good retention properties from 35 to $100{ }^{\circ} \mathrm{C}\left(\mathrm{t}_{5 \%} \sim 20\right.$ min and $Q_{\text {breakthrough }} \sim 90-100 \mathrm{mg} / \mathrm{g}$, Table 2). By contrast, significantly lower retention was achieved at $250^{\circ} \mathrm{C}\left(\mathrm{t}_{5 \%}=8 \mathrm{~min}, \mathrm{Q}_{\text {breakthrough }}=43 \mathrm{mg} / \mathrm{g}\right)$.

The shape of these breakthrough curves was found to be also apparently influenced by temperature (Figure $2(\mathrm{~A})$ ). This could be linked to the occurrence of by-products formed from $\mathrm{CH}_{3} \mathrm{I}$ reaction with silver sites. In that respect, it was found in our previous studies $[7,10]$ that $\mathrm{CH}_{3} \mathrm{I}$ adsorption can either occur molecularly (predominantly at low temperatures), or dissociatively due to the catalytic decomposition of methyl iodide on silver sites: 
$\mathrm{CH}_{3} \mathrm{I}+\mathrm{Ag} \rightleftharpoons \mathrm{C}$ by-products $+\mathrm{AgI}$

In the case of the experiment performed at $35{ }^{\circ} \mathrm{C}$, only methyl iodide was detected at the outlet of the fixed-bed reactor. This suggests that either molecular adsorption predominates or that organic by-products remained trapped within the zeolite pores. However, when the adsorption temperature was set to $100^{\circ} \mathrm{C}$, small amounts of dimethylether (DME) as well as traces of methanol (not quantified) were detected at the reactor outlet (Figure 2 (B)). As expected, the occurrence of catalytic decomposition processes became more significant at 250 ${ }^{\circ} \mathrm{C}$ leading to higher emissions of DME at much shorter reaction times. In the latter case, the evolution of higher alkanes with more than $1 \mathrm{C}$ atom was also observed, namely after $\mathrm{CH}_{3} \mathrm{I}$ breakthrough. Those products could not be formally identified and quantitated by our FTIR detection system due to the overlapping between their absorption features in the $\mathrm{CH}_{\mathrm{x}}$ and fingerprint spectral regions. The complex pathways involved in the formation of these $\mathrm{C}$ byproducts have been already reported in our previous works [7] and outlined the dual role of silver zeolite as iodine adsorbent and catalyst. As discussed with more details in the next section, oxygenated compounds such as DME are formed via surface reactions of adsorbed methoxy species (left from $\mathrm{CH}_{3} \mathrm{I}$ dissociation on silver cations or Brönsted acid sites) and methanol intermediates $[7,26,27]$. The mechanisms leading to higher hydrocarbons are beyond the scope of this study. Nevertheless, they were reported to form via a "Hydrocarbon Pool mechanism" involving methylation and hydrogenation/dehydrogenation reactions of those primary products, alkenes and decomposed methyl fragments [27].

Overall, the shortening of the breakthrough period as the adsorption temperature increased from 35 to $250{ }^{\circ} \mathrm{C}$ can be explained by different or phenomena: (i) higher $\mathrm{CH}_{3} \mathrm{I}$ dissociation rates at higher temperatures leading to more rapid transformation of unreacted (free) silver sites to AgI precipitates and the simultaneous production of carbonaceous adsorbates and gases. As the reaction progresses, the presence of catalytic by-products and AgI precipitates 
within the zeolite pores negatively affects the diffusion of incoming $\mathrm{CH}_{3} \mathrm{I}$ molecules, as indicated by data reported in Table $3\left(\mathrm{~L}_{\mathrm{T}} / \mathrm{L}\right.$ increases from 0.7 to 0.9 at $\left.250{ }^{\circ} \mathrm{C}\right)$. These diffusional limitations may induce preferential pathways inside the zeolitic sorbent, resulting in a significant decrease of breakthrough times and retention properties; (ii) less physisorption will occur at higher temperatures.

\subsubsection{Effect of water vapour}

The influence of $\mathrm{H}_{2} \mathrm{O}$ on $\mathrm{CH}_{3} \mathrm{I}$ retention by $22.8 \mathrm{Ag} / \mathrm{Y}(2.5)$ zeolite was investigated at $100{ }^{\circ} \mathrm{C}$ from experiments carried out under two distinct configurations: (i) co-adsorption of the mixture $\left(\left[\mathrm{CH}_{3} \mathrm{I}\right] /\left[\mathrm{H}_{2} \mathrm{O}\right]=1 / 8, \mathrm{~T}=100{ }^{\circ} \mathrm{C}\right)$ on the zeolite pre-treated under Ar at $500{ }^{\circ} \mathrm{C}(\mathrm{dry}$ zeolite) and (ii) $\mathrm{CH}_{3} \mathrm{I}$ adsorption alone onto a $\mathrm{H}_{2} \mathrm{O}$ pre-saturated zeolite $\left(3 \%\right.$ vol, $\mathrm{T}=100{ }^{\circ} \mathrm{C}$, total duration of 46 min). In Figure 3 (A) and (B) are displayed the $\mathrm{CH}_{3} \mathrm{I}$ and $\mathrm{H}_{2} \mathrm{O}$ signals, measured by on-line FTIR spectroscopy in the course of experiments (i) and (ii), respectively. The reference $\mathrm{CH}_{3} \mathrm{I}$ breakthrough curve measured under dry conditions corresponds to the curve already displayed on Figure $2(\mathrm{~A})\left(\mathrm{T}=100^{\circ} \mathrm{C}\right)$.

In presence of $\mathrm{CH}_{3} \mathrm{I}$ and water vapour introduced either simultaneously (Figure 3 (A)) or sequentially (Figure 3 (B)), oxygenated species, such as DME and $\mathrm{MeOH}$, were formed in much higher amounts than under dry conditions (Figure 2 (A)). For the $\mathrm{H}_{2} \mathrm{O}$-pre-saturated $\mathrm{Ag} / \mathrm{Y}$ zeolite (Figure $3(\mathrm{~B})$ ), desorption of zeolitic water started immediately as $\mathrm{CH}_{3} \mathrm{I}$ is sent through the zeolite bed. Water vapour emissions (corresponding to an "apparent" $\mathrm{H}_{2} \mathrm{O}$ adsorption capacity of $70 \mathrm{mg} / \mathrm{g}$ ) then progressively declined and vanished rapidly after $\mathrm{CH}_{3} \mathrm{I}$ breakthrough. This is probably due to adsorption competition phenomenon, which was at the advantage of $\mathrm{CH}_{3} \mathrm{I}$ at the studied temperature $\left(100{ }^{\circ} \mathrm{C}\right)$. It is worth noting that methanol and DME emissions accompany $\mathrm{CH}_{3} \mathrm{I}$ breakthrough, and are not observed from the beginning. $\mathrm{A}$ catalytic amount of $\mathrm{MeOH}$ was produced from the reaction of surface methoxy species with zeolitic water (Figure $3(\mathrm{~B})$ ). 
On the other hand, when the dry zeolite was exposed to a feed containing simultaneously $\mathrm{H}_{2} \mathrm{O}$ and $\mathrm{CH}_{3} \mathrm{I}$ (Figure $3(\mathrm{~A})$ ), both compounds were getting adsorbed simultaneously at the beginning of the experiment $\left(\mathrm{t}_{5 \%}=25\right.$ and $6 \mathrm{~min}$, for $\mathrm{CH}_{3} \mathrm{I}$ and $\mathrm{H}_{2} \mathrm{O}$, respectively, corresponding to a $\mathrm{H}_{2} \mathrm{O}$ adsorption capacity of $50 \mathrm{mg} / \mathrm{g}$ ). At $\mathrm{t}=13 \mathrm{~min}$, a sharp desorption of oxygenates (MeOH and DME) occurred simultaneously (Figure 3 (A)). Their emissions were noteworthy higher than those detected under dry conditions (Figure 2 (A)) and also higher than for the fully hydrated zeolite (Figure 3 (B)). Here also, a catalytic (steady-state) amount of methanol was formed at saturation of zeolite bed.

The following equations ( $\mathrm{ZO}^{-}$denotes the zeolitic framework) can be used to clarify the chemical processes occurring during these two experiments:

$$
\begin{aligned}
& \mathrm{CH}_{3} \mathrm{I}+\mathrm{ZOH} \rightleftharpoons \mathrm{ZOCH}_{3}+\mathrm{HI} \\
& \mathrm{CH}_{3} \mathrm{I}+\mathrm{ZOAg} \rightleftharpoons \mathrm{ZOCH}_{3}+\mathrm{AgI} \\
& \mathrm{ZOCH}_{3}+\mathrm{H}_{2} \mathrm{O} \rightleftharpoons\left(\mathrm{ZOCH}_{3}{ }^{++} \ldots \mathrm{OH}_{2}{ }^{\delta+} \ldots \mathrm{ZO}^{\delta-}\right) \rightleftharpoons \mathrm{CH}_{3} \mathrm{OH}+\mathrm{ZOH} \\
& \mathrm{CH}_{3} \mathrm{OH}+\mathrm{ZOH} \rightleftharpoons \mathrm{ZOCH}_{3}+\mathrm{H}_{2} \mathrm{O} \\
& \mathrm{CH}_{3} \mathrm{OH}+\mathrm{ZOCH} \rightleftharpoons\left(\mathrm{CH}_{3}^{\delta+} \ldots \mathrm{CH}_{3} \mathrm{OH}^{\delta+} \ldots \mathrm{ZO}^{\delta-}\right) \rightarrow \mathrm{CH}_{3} \mathrm{OCH}_{3}+\mathrm{ZOH} \\
& 2 \mathrm{CH}_{3} \mathrm{OH}+\mathrm{ZOH} \rightleftharpoons\left(\mathrm{CH}_{3} \mathrm{OH}^{\delta+} \ldots \mathrm{CH}_{3}^{\delta+} \ldots \mathrm{OH}_{2}^{\delta+} \ldots \mathrm{ZO}^{\delta-}\right) \rightleftharpoons \mathrm{CH}_{3} \mathrm{OCH}_{3}+\mathrm{H}_{2} \mathrm{O}+\mathrm{ZOH}
\end{aligned}
$$

At low-medium temperatures, a part of the adsorbed $\mathrm{CH}_{3} \mathrm{I}$ dissociated on Brönsted acid sites or silver cationic sites to yield surface methoxy species $\left(\mathrm{Si}\left(\mathrm{OCH}_{3}\right) \mathrm{Al}\right.$, while also forming $\mathrm{HI}$ or AgI as co-products, Eq. $3 \mathrm{a}$ and $3 \mathrm{~b}$ ). These steps also occurred under dry conditions but it has also to be reminded that a non-negligible fraction of $\mathrm{CH}_{3} \mathrm{I}$ molecules was adsorbed molecularly at $100{ }^{\circ} \mathrm{C}$ on silver $\mathrm{Y}$ zeolite, in line with our previous in situ IR study [7]. In presence of water vapour or zeolitic water, surface methoxy species could transform to gasphase methanol (Eq. 4a). Methanol produced through equation Eq. 4a could either adsorb reversibly as methoxy species (Eq. $4 \mathrm{~b}$, provided some free $\mathrm{OH}$ sites remain) or leave the pores, which allowed its detection by gas-phase FTIR. In that respect, $\mathrm{MeOH}$ emissions were 
observed in the gas phase only once the population within the pores of surface methoxy species and water reached a critical level (around $13 \mathrm{~min}$ in Figure $3(\mathrm{~A})$ and (B)), i.e. when reactions $3 \mathrm{a}, 3 \mathrm{~b}$ and $4 \mathrm{a}$ were displaced towards the formation of products.

From Figure 3, it can be deduced that DME was produced almost simultaneously to methanol, which confirms that the latter plays the role of intermediate in the reactions leading to DME. Two mechanisms, hard to distinguish experimentally, were proposed in the literature [26,27]. In the first one, methanol reacts with another surface methoxy to give DME while regenerating an acid site (Eq. 5a). On the other hand, a route involving the dehydration of two methanol molecules catalysed by an acid site could also lead to direct DME formation (Eq. $5 b)$.

(A)

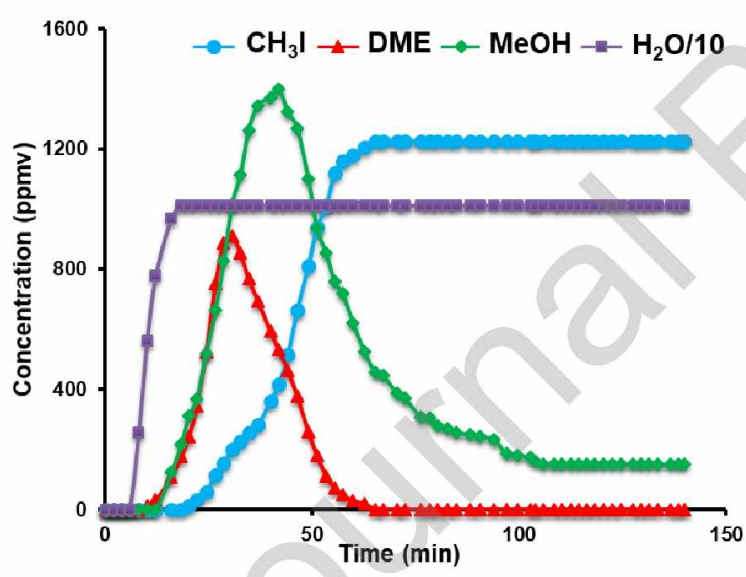

(B)

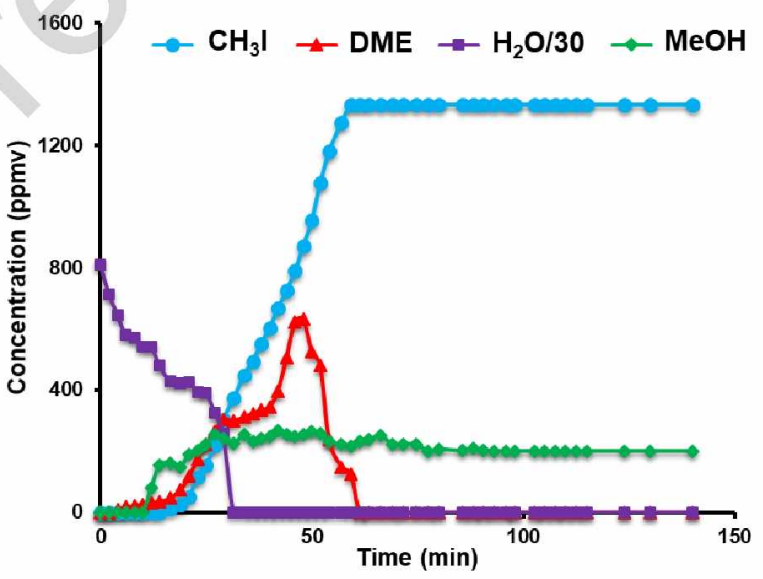

Figure $3: \mathrm{CH}_{3} \mathrm{I}$ breakthrough curves $\left(\mathrm{T}=100{ }^{\circ} \mathrm{C},\left[\mathrm{CH}_{3} \mathrm{I}\right]_{0}=1333 \mathrm{ppmv}\right)$ and evolution of oxygenated compounds: (A) co-adsorption of $\mathrm{CH}_{3} \mathrm{I}+$ water $(1 \% \mathrm{vol})$; (B) after being saturated by water $\left(\mathrm{T}=100{ }^{\circ} \mathrm{C}, 3 \% \mathrm{vol}\right)$.

After saturation of the zeolitic bed with $\mathrm{CH}_{3} \mathrm{I} / \mathrm{H}_{2} \mathrm{O}$ mixture, a steady-state $\mathrm{CH}_{3} \mathrm{I}$ concentration of $\approx 1200$ ppmv was measured (Figure $3(\mathrm{~A})$ ). This concentration is slightly lower than the nominal concentration $\left(\mathrm{C}_{0}=1333 \mathrm{ppmv}\right)$. Indeed, the transformation of $\mathrm{CH}_{3} \mathrm{I}$ to $\mathrm{MeOH}$ (about $150 \mathrm{ppmv}$ ) was catalyzed at $100{ }^{\circ} \mathrm{C}$ by the $\mathrm{Ag}(\mathrm{H}) / \mathrm{Y}$ zeolite and occurred at a constant rate at the end of the experiment. 
Table 3 : Influence of water vapour on $\mathrm{CH}_{3} \mathrm{I}$ retention properties of $22.8 \mathrm{Ag} / \mathrm{Y}(2.5)\left(\mathrm{T}=100{ }^{\circ} \mathrm{C},\left[\mathrm{CH}_{3} \mathrm{I}\right]_{0}=\right.$ 1333 ppmv)

\begin{tabular}{|ccccc|}
\hline Configuration & $\mathbf{Q}_{\text {sat }}(\mathbf{m g} / \mathbf{g})$ & $\mathbf{Q}_{\text {breakthrough }}(\mathbf{m g} / \mathbf{g})$ & $\mathbf{t}_{5 \%}(\mathbf{m i n})$ & $\mathbf{L}_{\mathrm{T}} / \mathbf{L}$ \\
\hline Dry atmosphere & $223 \pm 13$ & $90 \pm 10$ & $20 \pm 5$ & $0.70 \pm 0.02$ \\
\hline $\begin{array}{c}\text { Zeolite first saturated with water then } \\
\text { exposed to } \mathbf{C H}_{3} \mathbf{I}\end{array}$ & $200 \pm 12$ & $95 \pm 10$ & $21 \pm \pm 5$ & $0.61 \pm 0.02$ \\
\hline $\mathbf{C H}_{3} \mathbf{I}+\mathbf{H}_{\mathbf{2}} \mathbf{O}$ co-adsorption & & & & \\
\hline
\end{tabular}

From the different experiments carried out at $100{ }^{\circ} \mathrm{C}$ under dry and wet conditions, it can be stated that the ability of $22.8 \mathrm{Ag} / \mathrm{Y}(2.5)$ for $\mathrm{CH}_{3} \mathrm{I}$ retention was not really affected by the presence of steam in the studied conditions. Indeed, data reported in Table 3 indicated quasisimilar retention properties in terms of adsorption capacities (Qbreakthrough and $\mathrm{Q}_{\text {sat }}$ ). It is also worth noting that the presence of water led to an apparent decrease of diffusional limitations $\left(\mathrm{L}_{\mathrm{T}} / \mathrm{L}\right.$ about 0.60 against 0.70 in dry conditions, Table 4$)$. In that respect, in situ DRS-UV-Vis spectroscopic investigations were used to monitor the growth of $(\mathrm{AgI})_{\mathrm{n}}$ entities following $\mathrm{CH}_{3} \mathrm{I}$ adsorption $\left(\left[\mathrm{H}_{2} \mathrm{O}\right]=0\right.$ or $1 \%$ vol, $\left.\left[\mathrm{CH}_{3} \mathrm{I}\right]=667 \mathrm{ppmv}, \mathrm{T}=100{ }^{\circ} \mathrm{C}\right)$. Owing to quantum size effects in semi-conductors, the progressive redshift of AgI-related bands in the UV region was indicative of their coalescence to larger entities. In the course of the temperatureprogrammed desorption experiments carried out under argon after saturation of $\mathrm{Ag} / \mathrm{Y}$ zeolite with $\mathrm{CH}_{3} \mathrm{I}$ (see Figure S4), a more significant red-shift was observed in the presence of water, indicating the formation of larger AgI particles. Under humid conditions, the formation of a micro-solution within the pores may increase the mobility of silver and/or AgI species, thus promoting the growth of AgI precipitates [7]. These results could also be confronted to some 
literature works about other kinds of silver zeolites. Hence, Jubin [14,15] claimed that the presence of a moderate amount of water $\left(\left[\mathrm{CH}_{3} \mathrm{I}\right] /\left[\mathrm{H}_{2} \mathrm{O}\right] \sim 4.10^{-3}\right.$, temperature $100-150{ }^{\circ} \mathrm{C}$, R.H. $=5.6 \%$ at $100{ }^{\circ} \mathrm{C}$ and $1.2 \%$ at $150{ }^{\circ} \mathrm{C}$ ) is required in order to have high $\mathrm{CH}_{3} \mathrm{I}$ retention performances for $\mathrm{Ag}^{\circ} / \mathrm{MOR}$ zeolites ( $\mathrm{Si} / \mathrm{Al}$ of 10). By contrast, for a more hydrophilic $\mathrm{Ag} / \mathrm{X}$ zeolite $(\mathrm{Si} / \mathrm{Al}$ ratio $=1.2, \mathrm{Ag}$ content $=16 \mathrm{wt} \%), \mathrm{H}_{2} \mathrm{O}$ was reported to have a rather detrimental effect, especially at low temperatures. For a hydrated $\mathrm{Ag} / \mathrm{X}$ zeolite at $25{ }^{\circ} \mathrm{C}$, Belapurkar et al. [17] indicated a $56 \%$ decrease of the $\mathrm{CH}_{3} \mathrm{I}$ adsorption capacity in comparison with the totally dehydrated zeolite (against only $17 \%$ in the $100-150{ }^{\circ} \mathrm{C}$ range). Owing to its higher $\mathrm{Si} / \mathrm{Al}$ ratio (2.5 against 1.2 for $\mathrm{Ag} / \mathrm{X}$ zeolites), silver faujasite $\mathrm{Ag} / \mathrm{Y}$ zeolites are expected to be more tolerant to humidity (under the tested conditions) and may be more convenient than previously investigated $\mathrm{Ag} / \mathrm{X}$ zeolites for nuclear applications [4].

Owing to limitations imposed by FTIR detection, it is worth recalling that the investigated conditions in bench $1\left(\left[\mathrm{CH}_{3} \mathrm{I}\right] /\left[\mathrm{H}_{2} \mathrm{O}\right]=1 / 8\right)$ are still far away from those possibly encountered in a severe nuclear accident $\left(\left[\mathrm{CH}_{3} \mathrm{I}\right] /\left[\mathrm{H}_{2} \mathrm{O}\right]<\sim 10^{-6}\right.$ based on 1 ppmv of $\mathrm{CH}_{3} \mathrm{I}$ and $50 \%$ vol of $\mathrm{H}_{2} \mathrm{O}$ in the atmosphere [4]). Additional tests with more representative $\left[\mathrm{CH}_{3} \mathrm{I}\right] /\left[\mathrm{H}_{2} \mathrm{O}\right]$ ratios will be examined in later sections (see 3.2 and 3.3)

\subsection{Temporal evolution of $\mathrm{CH}_{3} I$ decontamination by silver faujasite zeolites under lab-scale “dry" conditions}

In the experiments presented before (test bench 1) and in our previous studies $[9,10]$, theoretical DF superior to $10^{2}$ could not be measured due to the rather low sensitivity of the FTIR detection setup. In order to measure more accurate DFs, a PDECD chromatographic method was used (test bench 2). It allowed performing breakthrough experiments with much lower $\mathrm{CH}_{3} \mathrm{I}$ inlet concentrations ( $1 \mathrm{ppmv}$ ), up to a detection limit of $10 \mathrm{pptv}$ (corresponding to a DF of $10^{5}$ ). This range of concentrations corresponds to what is expected in severe accident conditions. Overall, the $\mathrm{CH}_{3} \mathrm{I}$ decontamination behaviour of a given zeolitic sorbent in the 
initial period (before or at the beginning of the sorbent breakthrough) could be studied with a more accuracy.

Here, several silver faujasite zeolites of $\mathrm{Ag} / \mathrm{X}$ and $\mathrm{Ag} / \mathrm{Y}$ types, with silver content ranging between 0 and $35 \mathrm{wt} \%$, were compared. A summary of their most important physico-chemical properties is given in Table S2. Elemental silver and sodium contents, specific surface areas, silver oxidation states and locations, as well as their adsorption capacities at breakthrough and saturation, were already discussed in detail in $[9,10]$. Briefly, it can be outlined that all these silver-exchanged zeolites were characterized by a rather good dispersion of silver species in their framework, even at high silver content. For $\mathrm{Ag} / \mathrm{Y}$ zeolites, the major part of silver was found to be present as cationic $\mathrm{Ag}^{+}$species at exchange positions, whereas a minor part consisted of $\mathrm{Ag}_{\mathrm{n}}{ }^{+}$and $\mathrm{Ag}_{\mathrm{m}}^{\circ}$ embedded clusters of a few atoms [9]. By contrast, a noteworthy higher proportion of silver was found to be present as clusters in $\mathrm{Ag} / \mathrm{X}$ zeolites or as very small nanoparticles in the commercial $35 \mathrm{Ag} / 13 \mathrm{X}_{\text {comm }}$ zeolite with the highest silver loading [9]. Finally, it could be deduced from SEM micrographs shown in Figure S1, that all $\mathrm{Ag} / \mathrm{X}$ zeolites have crystallites of mean size $0.5-5 \mu \mathrm{m}$, whereas those of $\mathrm{Ag} / \mathrm{Y}$ were much smaller $(0.1-1 \mu \mathrm{m})$.

The $\mathrm{CH}_{3} \mathrm{I}$ breakthrough curves determined at $25^{\circ} \mathrm{C}$ on this set of sorbents are given on Figure 4 (A) whereas the corresponding evolution of decontamination factors on a similar timescale is shown on Figure 4 (B). Quantitative data computed from these breakthrough experiments are gathered in Table 4 . The parameter $t_{\text {D.L }}$ corresponded to the time interval where DF values were at least equal or above $10^{5}$, whereas $t_{0.1 \%}$ and $t_{1 \%}$ represented the time periods needed for the DFs to decrease down to $10^{3}$ and $10^{2}$, respectively. For DF values below the threshold of $10^{2}$, more than $1 \%$ of radioactive iodine was expected to pass through the zeolitic sorbent, and the latter was then considered to be no more efficient. 
First, a NaX zeolite containing no silver (not shown on Figure 4 and Table 4) was also tested under similar conditions. The measurement of a DF value equal to 1 over the whole timescale of the breakthrough experiment indicated that this type of zeolite is not suitable for severe accident application. Interestingly, the corresponding $\mathrm{CH}_{3} \mathrm{I}$ adsorption capacity at saturation measured for $\mathrm{NaX}$ was far to be negligible (92 $\mathrm{mg} / \mathrm{g}$ [12]), but this is not contradictory to the present result. It is expected that $\mathrm{CH}_{3} \mathrm{I}$ adsorption as physisorbed or weakly-chemisorbed species should result in much less stable trapping than its dissociation to stable AgI precipitates [10].

By contrast, all silver zeolites exhibited an improved behaviour, with initial DFs at least equal to $10^{5}$, thanks to the possibility of trapping methyl iodide as stable AgI precipitates. Considering first the series of $\mathrm{AgX}$ zeolites with different silver contents (7.3, 23.4 and 35 wt $\%$ ), it can be deduced from Figure 4 and Table 4 , that the zeolite with intermediate silver content $(23.4 \mathrm{wt} \%)$ displayed the best trapping behaviour. For this peculiar zeolite, very high $t_{D . L}, t_{0.1 \%}$ and $t_{1 \%}$ parameters were determined all along the total retention period and up to the beginning of breakthrough. On the one hand, this result is well in line with the conclusions of our former studies $[9,10,12]$, i.e. a high amount of dispersed silver species resulted in a higher amount of methyl iodide trapped as AgI precipitates. On the other hand, it also shows that, as the amount of silver reached a certain threshold within the zeolite pores (around $25 \mathrm{wt} \%$ for $\mathrm{Ag} / \mathrm{X}$ ), some silver aggregation occurred and the incoming $\mathrm{CH}_{3} \mathrm{I}$ molecules probably met some steric constraints in diffusing through the crystallites to reach the most buried silver sites, resulting also in a slightly less efficient adsorption (case of commercial $35 \mathrm{Ag} / 13 \mathrm{X}_{\text {comm }}$ (1.2) zeolite with $35 \mathrm{wt} \%$ silver). In that respect, the DRS-UV-Vis spectra shown previously [9] revealed a higher proportion of aggregated silver as small nanoparticles in $35 \mathrm{Ag} / 13 \mathrm{X}_{\mathrm{comm}}$ (1.2) in comparison with $23 \mathrm{Ag} / 13 \mathrm{X}(1.2)$. This also confirms the results from our last study devoted to the effect of silver speciation on the adsorption of $\mathrm{CH}_{3} \mathrm{I}$, indicating that the 
dispersed cationic species were more efficient than silver nanoparticles for methyl iodide trapping [12].

Finally, it is worth noting that the best decontamination was achieved with the $22.8 \mathrm{Ag} / \mathrm{Y}(2.5)$ zeolite. By comparison with the $\mathrm{Ag} / \mathrm{X}$ zeolite bearing a similar silver content $(23.4 \mathrm{wt} \%)$, the parameters displayed in Table 4 exhibited a substantial improvement of $\approx 70 \%$ at $\mathrm{t}_{\text {D.L. }}$ and of $\approx 40 \%$ at $\mathrm{t}_{1 \%}$. Two complementary explanations can be invoked. First, the $\mathrm{Ag} / \mathrm{Y}$ zeolite displays the highest proportion of silver present as dispersed cationic species of all tested zeolites in agreement with our previous DRS-UV-Vis investigations [9]. This is also consistent with the results of our former study indicating that this $\mathrm{Ag} / \mathrm{Y}$ zeolite displayed the highest fraction of methyl iodide trapped as $\mathrm{AgI}(78 \%)$, and the lower physisorbed $\mathrm{CH}_{3} \mathrm{I}$ fraction (9\%), the remaining being stored as chemisorbed $\mathrm{CH}_{3} \mathrm{I}[10]$. Second, it was also deduced from SEM analyses (Figure $\mathrm{S} 1$ ) that the mean crystallite size in $\mathrm{Ag} / \mathrm{Y}$ was significantly lower than that of $\mathrm{Ag} / \mathrm{X}$. Hence, it can be reasonably understood that the diffusion of methyl iodide in small crystals is easier than in larger ones. For the latter, defects and irregularities are more expected to be present, and could result in uneven diffusion of methyl iodide from the surface to the bulk of the crystals, this negatively affecting the trapping behaviour of $\mathrm{Ag} / \mathrm{X}$ zeolites during the initial adsorption period.

Overall, it is deduced from Table 4 and Figure 4 that the $\mathrm{Ag} / \mathrm{Y}$ zeolite with $23 \mathrm{wt} \%$ silver behaved as the best filter in model conditions, maintaining reasonably good filtration properties $\left(\mathrm{DF}>10^{2}\right.$ ) during more than 12 days. This corresponds to a useful working capacity of $156 \mathrm{mg} / \mathrm{g}$ and to a global silver use (I/Ag) of about 0.5 . For a fixed silver content, the retention in $\mathrm{Ag} / \mathrm{X}$ and $\mathrm{Ag} / \mathrm{Y}$ zeolites is influenced both by the proportion of silver present at exchange positions and the size/quality of zeolite cristallites. 
Table 4 : $\mathrm{CH}_{3} \mathrm{I}$ breakthrough curves and decontamination factors measured for $\mathrm{Ag} / \mathrm{X}$ and $\mathrm{Ag} / \mathrm{Y}$ zeolites $\left(\left[\mathrm{CH}_{3} \mathrm{I}\right]_{0}=1 \mathrm{ppmv}, \mathrm{T}=25^{\circ} \mathrm{C}\right.$, total gas flow rate $\left.=150 \mathrm{NmL} \cdot \mathrm{min}^{-1}\right)$

\begin{tabular}{|c|c|c|c|c|c|}
\hline Sample & $\mathbf{t}_{\text {D.L (min) }}$ & $t_{0.1 \%}(\min )$ & $\mathbf{Q}_{0.1 \%}(\mathrm{mg} / \mathrm{g})$ & $t_{1 \%}(\min )$ & $\mathbf{Q}_{1 \%}(\mathrm{mg} / \mathrm{g})$ \\
\hline $7.3 \mathrm{Ag} / 13 \mathrm{X}(1.2)$ & 0 & 4151 & 37 & 5168 & 46 \\
\hline $23.4 \mathrm{Ag} / 13 \mathrm{X}(1.2)$ & 7295 & 9982 & 88 & 12701 & 113 \\
\hline $35 \mathrm{Ag} / 13 \mathrm{X}_{\text {comm }}(1.2)$ & 62 & 7932 & 65 & N. D & N. D \\
\hline $22.8 \mathrm{Ag} / \mathrm{Y}(2.5)$ & 12405 & 15767 & 135 & 18222 & 156 \\
\hline
\end{tabular}
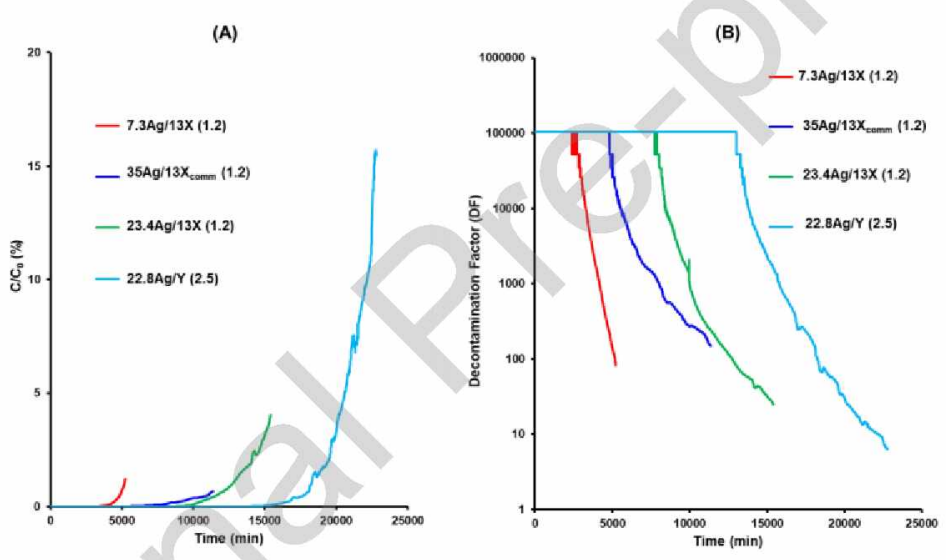

Figure $4: \mathrm{CH}_{3} \mathrm{I}$ breakthrough curves and temporal evolution of the corresponding decontamination factors (represented in logarithmic scale) for $\mathrm{Ag} / \mathrm{X}$ and $\mathrm{Ag} / \mathrm{Y}$ zeolites $\left(\left[\mathrm{CH}_{3} \mathrm{I}_{0}=1 \mathrm{ppmv}, \mathrm{T}=25^{\circ} \mathrm{C}\right.\right.$, total gas flow rate $=150 \mathrm{NmL} \cdot \mathrm{min}^{-1}$ ).

\section{3. $\mathrm{CH}_{3}$ I retention performances by silver-exchanged faujasite zeolites at semi pilot scale}

In this section, the ability of silver-exchanged faujasite zeolites towards the retention of very low concentrations of methyl iodide $(\approx 0.15 \mathrm{ppmv})$ was investigated within a semi-pilot configuration in presence of humidity. The main purpose of this work was to determine the behaviour of silver zeolites under wet conditions closer to those expected to occur during nuclear severe accident, i.e. low molar $\left[\mathrm{CH}_{3} \mathrm{I}\right] /\left[\mathrm{H}_{2} \mathrm{O}\right]$ ratio (of the order of $10^{-6}$ ). For practical reasons related to the necessity to use high amounts of sorbent, most of the tests were conducted on the commercial Ag/X zeolite (with $35 \mathrm{wt} \%$ of silver) already tested in part 3.2 . and in our other studies [9-11]. Zeolitic sorbents were diluted with inert sand in order to 
achieve sufficient bed depths. A parametric study was implemented in order to determine the most influencing parameters for $\mathrm{CH}_{3} \mathrm{I}$ sorption. These parameters could be classified in two categories:

(i) parameters related to the adsorbent: silver content, grain size, bed depth and zeolite type $(\mathrm{X}$ or $\mathrm{Y})$;

(ii) parameters related to the gas mixture containing $\mathrm{CH}_{3}{ }^{131} \mathrm{I}$ : initial activity, temperature, relative humidity, face velocity and residence time.

The conditions used for each operated test and the measured decontamination factors are summarized in Table 5. As stated in the experimental part, $\mathrm{CH}_{3} \mathrm{I}$ decontamination factors (DF) were deduced from $\gamma$-spectrometry counting carried out both on upstream and downstream stages. The measured activities are detailed in the ESI (see Table S4)

First, it can be noticed that silver faujasite materials exhibit rather poor retention performances at low temperature and high relative humidity $\left(\mathrm{T} \approx 20^{\circ} \mathrm{C}, \mathrm{R} . \mathrm{H} . \approx 80-90 \%\right.$, DF ranging from 2 to 12 , Table 5). This behavior may be related to the predominance of $\mathrm{CH}_{3} \mathrm{I}$ molecular adsorption over the formation of AgI precipitates at these low temperatures $[6,23,24]$. At $20{ }^{\circ} \mathrm{C}$ and for a $\left[\mathrm{CH}_{3} \mathrm{I}\right] /\left[\mathrm{H}_{2} \mathrm{O}\right]$ molar ratio of $6 \times 10^{-6}$, the adsorption $\mathrm{H}_{2} \mathrm{O}$ is probably promoted at the expense of $\mathrm{CH}_{3} \mathrm{I}$ adsorption due to the relatively high hydrophilicity of faujasite $[7,26,27]$.

At higher temperatures $\left(75-100{ }^{\circ} \mathrm{C}\right)$, a strong enhancement in decontamination factors is observed. It is important to bear in mind here that the $\left[\mathrm{CH}_{3} \mathrm{I}\right] /\left[\mathrm{H}_{2} \mathrm{O}\right]$ ratio was similar to the experiments carried out at $20^{\circ} \mathrm{C}$ but this corresponded to a much lower R.H. due to the rapid increase of water vapour pressure in this range of temperatures. Indeed, DF values significantly increased from $10(A g-X$ granular R.T 1 , Table 5$)$ to $\approx 2.5 .10^{4}$ at least $(A g-X$ gramular H.T 16, Table 5) when the temperature was varied from $20.0^{\circ} \mathrm{C}(\mathrm{R} . \mathrm{H} .=76.7 \%)$ to $74.6{ }^{\circ} \mathrm{C}(\mathrm{R} . \mathrm{H} .=7.6 \%)$. This result has probably to be attributed to a higher dissociation rate 
of methyl iodide molecules as the temperature increases, leading therefore to a higher formation of stable AgI entities within the zeolite cages [6]. On the other hand, physisorption phenomena responsible for water adsorption are also expected to be much less promoted at $75-100{ }^{\circ} \mathrm{C}[6,23,24]$. Overall, the presence of water vapour in large excess $\left(\left[\mathrm{CH}_{3} \mathrm{I}\right] /\left[\mathrm{H}_{2} \mathrm{O}\right] \approx\right.$ $6 \times 10^{-6}$ ) was found to be much less inhibiting as temperatures are getting closer to those expected in severe accident conditions

Table 5 : Summary of the $\mathrm{CH}_{3} \mathrm{I}$ retention performances of $\mathrm{Ag}-\mathrm{X}$ and $\mathrm{Ag}-\mathrm{Y}$ zeolites at different conditions

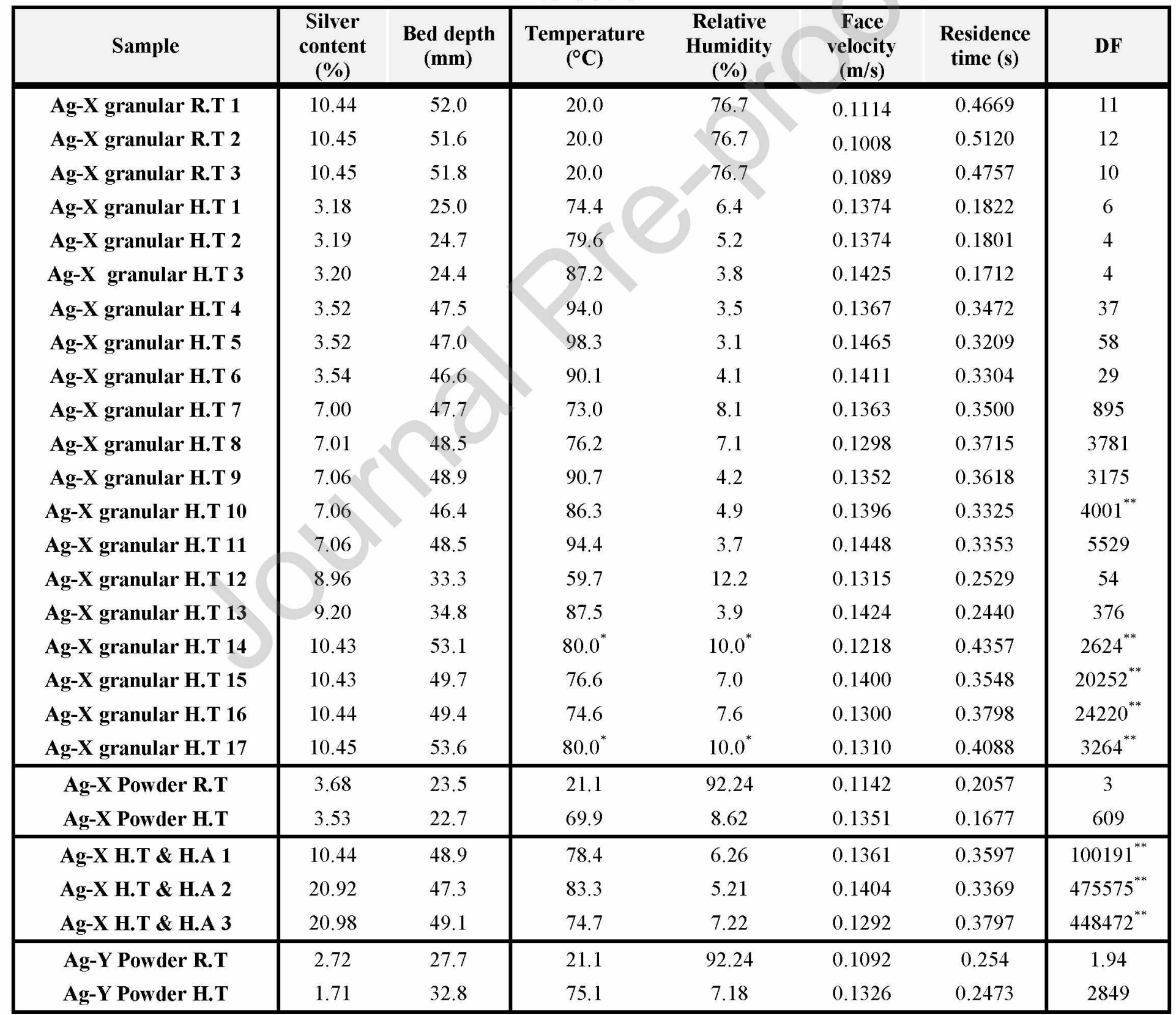


R.T $=$ Room Temperature, H.T: High Temperature (about $80^{\circ} \mathrm{C}$ ), H.A: High Activity of 500 instead of 50 $\mathrm{kBq} / \mathrm{sample}$. "These parameters were not monitored during the test. $* *$ The reported value is considered as the minimal DF that can be reached, since any peak related to ${ }^{131} \mathrm{I}$ was detected by $\gamma$-spectrometry on the downstream filter.

According to the above, a peculiar attention will thereafter be devoted to the heated samples (75-100 ${ }^{\circ} \mathrm{C}$ in our case). Among the different parameters considered in this study, let us focus now on the effect of silver content on $\mathrm{CH}_{3} \mathrm{I}$ retention by Ag-X zeolites. In that respect, quasilinear relationships between $\mathrm{CH}_{3} \mathrm{I}$ adsorption capacities (both $\mathrm{Q}_{\text {sat }}$ and $\mathrm{Q}_{\text {breakthrough }}$ ) and silver content were established previously $\left(\left[\mathrm{CH}_{3} \mathrm{I}\right]_{0}=1333 \mathrm{ppmv} / \mathrm{Ar}, \mathrm{T}=100{ }^{\circ} \mathrm{C}\right.$, dry atmosphere, lab-scale conditions) $[9,10]$. In the present study, an increasing relationship between DF values and silver content was also found for $\mathrm{Ag}-\mathrm{X}$ (granular) samples, especially when silver amount is ranging from 3 to $7 \mathrm{wt} \%$ (Figure 5 , in log scale, bed depth of $50 \mathrm{~mm}$ ).

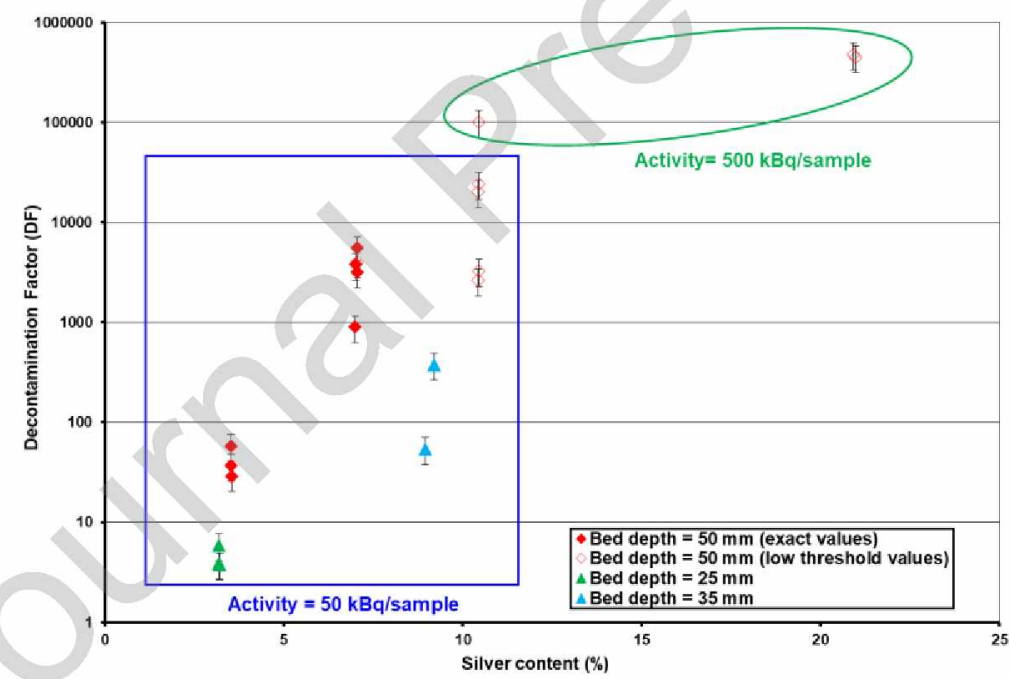

Figure 5 : Evolution of $\mathrm{CH}_{3} \mathrm{I}$ decontamination factors (logarithmic scale) as a function of silver content for some $\mathrm{Ag}$-X granular zeolites $\left(\mathrm{T} \approx 80^{\circ} \mathrm{C}, \mathrm{R} . \mathrm{H} . \approx 10 \%,\left[\mathrm{CH}_{3} \Pi_{0}=0.15 \mathrm{ppmv} /\right.\right.$ Air $)$.

Nevertheless, significant deviations from this relationship were also observed at higher silver contents (Figure 5). This may be related to the different parameters employed for each test/sample. The first one is assigned to a lower bed depth in the case of $A g-X$ gramular H.T 13. Indeed, the latter sample displays a bed depth of $34.8 \mathrm{~mm}$ against about $50.0 \mathrm{~mm}$ for almost all the other investigated samples (Table 5). It is worth mentioning that, for a same gas 
velocity lowering the bed depth would result in shorter residence times for the $\mathrm{CH}_{3} \mathrm{I}$ molecules within the filter. This may create preferential pathways inside the sorbent, which negatively impacts its filtering properties. This trend seems to be consistent with previous studies dealing with $\mathrm{CH}_{3} \mathrm{I}$ retention at different face velocities $[28,29]$.

For silver content of $10 \mathrm{wt} \%$ (Ag-X granular H.T 14, 15, 16 and 17 samples), it was observed that almost of the labeled $\mathrm{CH}_{3}{ }^{131}$ I was captured by the adsorbent. In other words, the fraction of methyl iodide at the counting stage was found to be very close to the detection limit, which induces huge errors of counting. Consequently, the reported DF values should be considered as the minimal performances that can be reached by our zeolitic sorbents. In order to overcome these analytical limitations, a first attempt was made by performing additional tests with higher initial activities (500 instead of $50 \mathrm{kBq} / \mathrm{sample}$ ). Here also, a significant uncertainty of activity measurement in the downstream stage was observed due to almost total capture of methyl iodide by the zeolite. Nevertheless, a noteworthy increase in the retention performances towards $\mathrm{CH}_{3} \mathrm{I}$ could be outlined in that configuration. Indeed, Ag-X granular zeolites exhibited minimal DF values of $10^{5}$ and $5 \times 10^{5}$ for silver contents about 10 and 20 wt $\%$, respectively, when using an initial activity of $500 \mathrm{kBq} / \mathrm{sample}$ instead of $50 \mathrm{kBq} / \mathrm{sample}$ (Table 5). Even more accurate DF measurements could perhaps be performed at higher initial activity but a compromise should be also found in order to meet the radioprotection regulations related to our facility. To sum up, it is clear that silver content played a key role in order to enhance methyl iodide capture by $\mathrm{Ag}-\mathrm{X}$ zeolites at representative conditions of severe nuclear accident, consistently with our previous findings obtained under lab-scale conditions $[9,10]$. Bed depth and residence time played also a role in $\mathrm{CH}_{3} \mathrm{I}$ retention, especially at high silver content. 
The comparison between performances displayed by $A g$-X granulated H.T samples (4, 5, 6) and the $A g-X$ powdered H.T sample (Table 5), may either indicate that grain size played a major role for methyl iodide retention or alternatively, that the powder was more easily dispersed within the diluting sand. Indeed, the decrease of grain size by crushing pellets with a mean size of $841 \mu \mathrm{m}$ to a fine powder led to a pronounced increase of DF values from (3060) to 609 (Table 5). Moreover, a closer look to the characteristics of these samples indicated a similar silver content (about $3.5 \mathrm{wt} \%$ ) and higher bed depth for granulated samples (about $47 \mathrm{~mm}$ against $23 \mathrm{~mm}$ for the powder). Thus, it seemed that grain size was more influencing than the bed depth in this configuration. This result could be somewhat related to the wellknown enhancement of mass transfer phenomena of $\mathrm{CH}_{3} \mathrm{I}$ molecules within the adsorbent for a decreasing grain size $[30]$.

The comparison of the performances displayed by $\mathrm{Ag} / \mathrm{Y}$ and $\mathrm{Ag} / \mathrm{X}$ zeolites is now discussed. From the data gathered in Table 5, it could be immediately deduced that $\mathrm{Ag} / \mathrm{Y}$ zeolite was by far more efficient than $\mathrm{Ag} / \mathrm{X}$ for methyl iodide retention, even for lower silver contents and lower bed depths. This seems to be in line both with the results presented in part 3.2 (under dry conditions at lab-scale), and with our former studies $[9,10]$

Hence, the main conclusions of this parametric study could be summarized as follows: (i) rather poor $\mathrm{CH}_{3} \mathrm{I}$ retention performances were measured in presence of silver faujasites at room temperature and large excess of water vapour; (ii) at temperatures in the range $75-90{ }^{\circ} \mathrm{C}$, this inhibition is not really significant and high DF values could be reached. Indeed, the increase of temperature will increase the reaction rate between $\mathrm{CH}_{3} \mathrm{I}$ and silver species to form AgI precipitates at the expense of physisorption phenomena favoring the co-adsorption of $\mathrm{H}_{2} \mathrm{O}$ molecules; (iii) At high temperatures, the DF value is dependent mainly on the silver concentration in the bed (i.e. the silver content in the zeolite and the dilution factor with sand). 
However, other parameters such as bed depth, the residence time and the grain size were also found to play an important role in order to ensure $\mathrm{CH}_{3} \mathrm{I}$ retention with a high efficiency.

\section{Conclusions}

The present study aimed to assess the retention of methyl iodide by silver faujasite $\mathrm{Ag} / \mathrm{X}$ and $\mathrm{Ag} / \mathrm{Y}$ zeolites under extrapolated severe nuclear accident conditions.

Under dry conditions, $\mathrm{Ag} / \mathrm{Y}$ zeolite with $23 \mathrm{wt} \%$ of silver maintained high $\mathrm{CH}_{3} \mathrm{I}$ adsorption capacities over a wide range of temperatures $\left(20-250{ }^{\circ} \mathrm{C}\right)$, although a slight decrease was observed at $250^{\circ} \mathrm{C}$. At $25^{\circ} \mathrm{C}$ and very low $\mathrm{CH}_{3} \mathrm{I}$ concentrations ( $1 \mathrm{ppmv}$ ), DF values equal or superior to $10^{5}$ were maintained over 9 days for $\mathrm{Ag} / \mathrm{Y}$ zeolite, which is much better than for $\mathrm{Ag} / \mathrm{X}$ zeolites bearing similar or even higher silver contents. In comparison with $\mathrm{Ag} / \mathrm{X}$ zeolites, $\mathrm{Ag} / \mathrm{Y}$ zeolites with $23 \mathrm{wt} \%$ of silver exhibited better retention properties due to the presence of: (i) a higher proportion of $\mathrm{Ag}^{+}$species in its framework; (ii) a smaller crystal size and (iii) a higher $\mathrm{Si} / \mathrm{Al}$ ratio.

In the presence of moderate excess of water at $100^{\circ} \mathrm{C}$, the dissociation of $\mathrm{CH}_{3} \mathrm{I}$ to $\mathrm{AgI}$ species on $\mathrm{Ag} / \mathrm{Y}$ zeolite was accompanied by the catalytic production of gaseous oxygenated species such as methanol and dimethylether, without decreasing the $\mathrm{CH}_{3} \mathrm{I}$ adsorption capacities at breakthrough and saturation.

The presence of a large excess of water at the expense of methyl iodide $\left(\left[\mathrm{CH}_{3} \mathrm{I}\right] /\left[\mathrm{H}_{2} \mathrm{O}\right]\right.$ molar ratio $=6 \times 10^{-6}$ ) induced adverse effects depending on the adsorption temperature. A rather severe inhibition of $\mathrm{CH}_{3} \mathrm{I}$ adsorption on silver faujasite zeolites was observed near ambient temperature due to the promotion of water sorption at the expense of $\mathrm{CH}_{3} \mathrm{I}$ dissociation, leading to significantly lower DF values. Hopefully, these limitations were not found at higher temperatures more representative of a severe accident $\left(80-100{ }^{\circ} \mathrm{C}\right)$. Under these conditions, 
very good $\mathrm{CH}_{3} \mathrm{I}$ retention with DF values reaching $10^{4}-10^{5}$ or more were measured even after diluting the zeolite with sand, provided that the bed depth and overall silver content were above a critical level. Although the results obtained on $\mathrm{Ag} / \mathrm{Y}$ candidate zeolite are promising for a practical implementation in filtering containment venting system, more experiments will be carried out with silver faujasites in the future in order to further assess the effect of chemical inhibitors $\left(\mathrm{NO}_{\mathrm{x}}, \mathrm{CO}_{\mathrm{x}} \ldots\right)$ under accidental and ageing conditions.

\section{Acknowledgements}

This work has been supported by the French State under the program "Investissements d'Avenir MiRE managed by the ANR under grant agreement ANR-11-RSNR-0013-01. 
Graphical Abstract

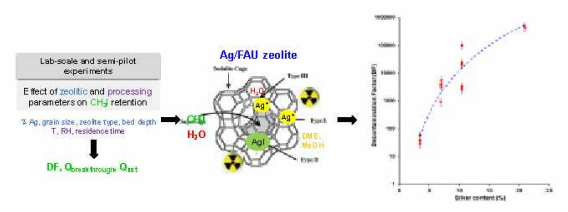




\section{Credit Author statement}

Mouheb Chebbi: Investigation, Methodology, Validation, Formal analysis, Writing - Original Draft, Writing - Review \& Editing.

Bruno Azambre: Conceptualization, Methodology, Supervision, Writing - Original Draft, Writing Review \& Editing.

Céline Monsanglant-Louvet: Supervision, Methodology, Writing - Review \& Editing.

Benoit Marcillaud: Investigation, Methodology.

Audrey Roynette: Investigation, Methodology.

Laurent Cantrel: Project administration, Funding acquisition, Writing - Review \& Editing. 


\section{Declaration of interests}

$\bigotimes$ The authors declare that they have no known competing financial interests or personal relationships that could have appeared to influence the work reported in this paper.

$\square$ The authors declare the following financial interests/personal relationships which may be considered as potential competing interests: 


\section{Highlights}

- $\mathrm{Ag} / \mathrm{FAU}$ zeolites are able to trap volatile iodine under humid conditions.

- The $\mathrm{CH}_{3} \mathrm{I}$ sorption capacity of $\mathrm{Ag} / \mathrm{Y}$ is globally maintained in the $35-250^{\circ} \mathrm{C}$ range.

- Higher decontamination factors were measured for $\mathrm{Ag} / \mathrm{Y}$ compared with $\mathrm{Ag} / \mathrm{X}$.

- The inhibiting effect of water vapour is more important at low temperatures.

- Ag content and bed depth are important in the context of severe nuclear accident. 


\section{References}

[1] Clement, B., Cantrel, L., Ducros, G., Funke, F., Herranz, L., Rydl, A., Weber, G., Wren, C., 2007. State of the art report on iodine chemistry, in: OCDE Report, NEA/CSNI/R.

[2] Haefner, D.R., Tranter, T.J., 2007. Methods of Gas Phase Capture of Iodine from Fuel Reprocessing Off-Gas: a Literature Survey, INL/EXT-07e12299, Idaho National Laboratory.

[3] Cantrel, L., Herranz, L.E., Guieu, S., Albiol, T., Collet, R., Lind, T., Karkela, T., Mun, C., Jacquemain, D., Chebbi, M., 2015. Overview of ongoing and planned R\&D works on delayed releases and FCVS efficiencies, in: Proceedings of ICAPP 2015, Nice (France).

[4] Herranz, L.E., Lind, T., Dieschbourg, K., Riera, E., Morandi, S., Rantanen, P., Chebbi, M., Losch, N., 2013. State of the Art Report: Technical Bases for Experimentation on Source Term Mitigation Systems, Passam-TheorT04 [D2.1].

[5] Huve, J., Ryzhikov, A., Nouali, H., Lalia, V., Augé, G., Daou, T.J., 2018. Porous sorbents for the capture of radioactive iodine compounds: a review. RSC Adv. 8, 29248-29273. https://doi.org/10.1039/C8RA04775H.

[6] Chebbi, M., 2016. Piégeage d'espèces iodées volatiles sur des adsorbants poreux de type zéolithique dans le contexte d'un accident nucléaire grave. Thèse, Université de Lorraine, 2016.

[7] Chebbi, M., Azambre, B., Cantrel, L., Koch, A., 2016. A combined DRIFTS and DR-UV-Vis spectroscopic in situ study on the trapping of $\mathrm{CH}_{3} \mathrm{I}$ by silver-exchanged faujasite zeolite. J. Phys. Chem. C 120, 18694-18706. https://doi.org/10.1021/acs.jpcc.6b07112.

[8] Chebbi, M., Chibani, S., Paul, J.F., Cantrel, L., Badawi, M., 2017. Evaluation of volatile iodine trapping in presence of contaminants: A periodic DFT study on cation exchanged-faujasite. Microporous Mesoporous Mater. 239, 111-122. https://doi.org/10.1016/j. micromeso.2016.09.047.

[9] Chebbi, M., Azambre, B., Cantrel, L., Huvé, M., Albiol, T., 2017. Influence of structural, textural and chemical parameters of silver zeolites on the retention of methyl iodide. Microporous Mesoporous Mater. 244, 137-150. https://doi.org/10.1016/j.micromeso.2017.02.056.

[10] Azambre, B., Chebbi, M., 2017. Evaluation of silver zeolites sorbents toward their ability to promote stable $\mathrm{CH}_{3} \mathrm{I}$ storage as AgI Precipitates. ACS Appl. Mater. Interfaces 9(30), 25194-25203. https://doi.org/10.1021/acsami.7b02366.

[11] Azambre, B., Chebbi, M., Leroy, O., Cantrel, L., 2018. Effects of zeolitic parameters and irradiation on the retention properties of silver zeolites exposed to molecular iodine. Ind. Eng. Chem. Res. 57(5), 1468-1479. https://doi.org/10.1021/acs.iecr.7b03579.

[12] Azambre, B., Chebbi, Hijazi, A., 2020. Effects of the cation and $\mathrm{Si} / \mathrm{Al}$ ratio on $\mathrm{CH}_{3} \mathrm{I}$ adsorption by faujasite zeolites. Chem. Eng. J. 379, 122308. https://doi.org/10.1016/j.cej.2019.122308.

[13] Flanigen, E.M., 1991. in: H. van Bekkum, E.M. Flanigen, J.C. Jansen (Eds.), Introduction to Zeolite Science and Practice, Studies in Surface Science and Catalysis. Stud. Surf. Sci. Catal., Elsevier, Amsterdam.

[14] Jubin, R.T., 1980. Organic iodine removal from simulated dissolver Off-Gas streams using silver-exchanged Mordenite. Proceedings of the $16^{\text {th }}$ Air Cleaning Conference, San Diego, California (USA).

[15] Jubin, R.T., 1982. Organic Iodine Removal from Simulated Dissolver Off-Gas Systems Using Partially Exchanged Silver Mordenite. Proceedings of the $17^{\text {th }}$ Air Cleaning Conference, Denver, Colorado (USA).

[16] Choi, B. S., Park, G.I., Lee, J.W., Yang, H.Y., Ryu, S.K., 2003. Performance test of silver ion-exchanged zeolite for the removal of gaseous radioactive methyl iodide at high temperature condition. J. Radioanal. Nucl. Chem. 256, 19-26. https://doi.org/10.1023/a:1023383505788.

[17] Belapurkar, A.D, Rao, K.A., Gupta, N.M., Iyer, R.M., 1984. On the interactions of $\mathrm{CH}_{3} \mathrm{I}$ over silverexchanged molecular sieves. Surf. Technol. 21, 263-272. https://doi.org/10.1016/0376-4583(84)90088-8. 
[18] Chebbi, M., Azambre, B., Volkringer, C., Loiseau, T., 2018. Dynamic sorption properties of Metal-Organic Frameworks for the capture of methyl iodide. Microporous Mesoporous Mater. 259, 244-254. https://doi.org/10.1016/j.micromeso.2017.10.018.

[19] Antoine, C., 1888. Comptes Rendus des Séances de l'Académie des Sciences (in French) 107, 681-684, 778$780,836-837$.

[20] Cantrel, L., Albiol, T., Bosland, L., Colombani, J., Cousin, F., Grégoire, A-C., Leroy, O., Morin, S., Mun, C., Ohnet, M-N., Souvi, S., Monsanglant-Louvet, C., Louis, F., Azambre, B., Volkringer, C., 2018. Research works on iodine and ruthenium behavior in severe accident conditions. J. Nucl. Eng. Radiat. Sci. 4 (2), 1-13. https://doi.org/10.1115/1.4038223.

[21] Forsyth, D.S., 2004. Pulsed discharge detector: theory and applications, J. Chromatogr. A. 1050, 63-68. https://doi.org/10.1016/j.chroma.2004.07.103.

[22] Leroy, O., Monsanglant-Louvet, C., 2019. Trapping measurements of volatile iodine by sand bed and metallic filters. J. Radioanalytical. Nuclear. Chem. 322, 913-922. https://doi.org/10.1007/s10967-019-06786-1.

[23] Park, G.I., Kim, I.T., Lee, J.K., Ryu, S.K., Kim, J.H., 2001. Effect of temperature on the adsorption and desorption characteristics of methyl iodide over TEDA-impregnated activated carbon. Carbon Sci. 2, 9-14.

[24] Park, S.W., Park, H.S., Lee, W.K., Moon, H., 1995. Effect of water-vapor on adsorption of methyl-iodide to triethylenediamine-impregnated activated carbons. Sep. Technol. 5, 35-44. https://doi.org/10.1016/09569618(94)00104-Z.

[25] Choi, B.S., Park, G.I., Kim, J.H., 2001. Adsorption equilibrium and dynamics of methyl iodide in a silver ionexchanged zeolite column at high temperatures. Adsorption 7, 91-103. https://doi.org/10.1023/A:1011660121182.

[26] Nenoff, T.M., Rodriguez, M., Soelberg, N., Chapman, K.W., 2014. Silver-mordenite for radiologic gas capture from complex streams: Dual catalytic $\mathrm{CH}_{3} \mathrm{I}$ decomposition and I confinement. Microporous Mesoporous Mat. 200, 297-303. https://doi.org/10.1016/j.micromeso.2014.04.041.

[27] Khadzhiev, S.N., Magomedova, M.V., Peresypkina, E.G., 2014. Mechanism of olefin synthesis from methanol and dimethyl ether over zeolite catalysts: A review. Petroleum Chem. 54, 243-269. https://doi.org/10.1134/S0965544114040057.

[28] Pence, D.T., Duce, F.A., Maeck, W.J., 1970. A study of the adsorption properties of metal zeolites for airborne iodine species. Proceeding of the $11^{\text {th }}$ DOE/NRC Nuclear Air cleaning and Treatment Conference, Richland, Washington (USA).

[29] Scheele, R.D., Burger, L.L., Matsuzaki, C.L., 1983. Methyl Iodide Sorption by Reduced Silver Mordenite. Pacific Northwest Laboratory Operated for the U.S. Department of Energy by Battelle Memorial Institute, PNL4489 .

[30] Landaverde-Alvarado, C., Morris, A.J., Martin, S.M., 2017. Gas sorption and kinetics of $\mathrm{CO}_{2}$ sorption and transport in a polymorphic microporous MOF with open $\mathrm{Zn}$ (II) coordination sites. J. CO2 utilization 19, 40-48. https://doi.org/10.1016/j.jcou.2017.01.029. 